CELSI Discussion Paper No. 23

DI D POST - ENLARGEMENT

LABOR MOBILITY HELP THE

EU TO ADJ UST DURING THE

GREAT RECESSI ON? THE

CASE OF SLOVAKIA

June 2014

MARTI N KAHANEC

LUCI A MYTNA KUREKOVA 


\title{
Did post-enlargement labor mobility help the EU to adjust during the Great Recession? The case of Slovakia
}

\author{
CELSI Discussion Paper No. 23 \\ June 2014
}

\section{Martin Kahanec}

Central European University, IZA and CELSI

\section{Lucia Mýtna Kureková}

SI ovak Governance Institute, CEU and CELSI

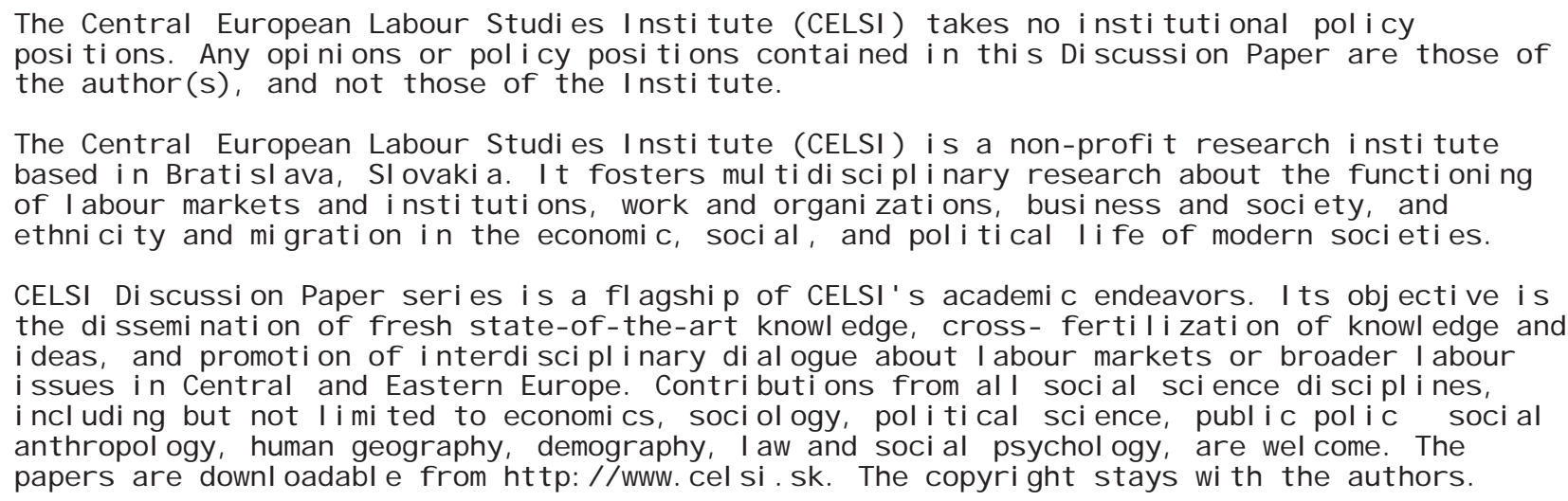

Central European Labour Studies Institute (CELSI)

$\begin{array}{ll}\text { Zvolenská } 29 & \text { Tel/Fax: +421-2-20735767 } \\ 821 \text { og Bratislava } & \text { E-mail: info@celsi.sk } \\ \text { Slovak Republic } & \text { Web: www. celsi.sk }\end{array}$


CELSI Discussion Paper No. 23

J une 2014

\section{ABSTRACT \\ Did post-enlargement labor mobility help the EU to adjust during the Great Recession? The case of Slovakia}

This paper evaluates the mobility patterns of slovaks into the rest of the European Union (EU) following Slovakia's EU accession in 2004 and through the Great Recession. Combining information from various data sources including the Slovak Labor Force survey and conducting our own statistical analysis of selectivity into migration, we study whether and how migration responded to asymmetric economic shocks at home and abroad. we identify a number of shifts in the directionality and composition of migration flows in terms of the destinations, gender, age, educational attainment and occupation, reflecting changing labor market conditions in receiving countries and slovakia. We show that besides the standard demographic factors, migration propensity was higher among the unemployed and from the more depressed regions of slovakia. We conclude that 1abor migration has served as an important adjustment mechanism in the country and more generally in the EU labor market.

Keywords: Adjustment, EU enlargement, labor market, migration, Slovakia

JEL Classification: F22, J61

\section{Corresponding Author:}

Martin Kahanec

Department of Public Policy, Central European University Nádor u. 9, H- 1051 Budapest, Hungary

E-mai I: kahanecm@ceu.hu

\footnotetext{
* Acknowledgements: This paper was written within IZA's research sub-area "EU enlargement and the labor markets". We are grateful to the participants of the 5th IZA/CEUR Workshop on "EU Enlargement and the Labor Markets: Migration, Crisis and Adjustment in an Enlarged E(M)U II" for providing a number of suggestions that helped to improve the paper significantly. We thank the slovak statistical office for providing the slovak Labor Force Survey data. Any remaining errors are ours.
} 


\section{Introduction}

Although membership in the European Union (EU) looked like a distant dream to many Slovaks in the 1990s, a remarkable political and economic makeover around the turn of the millennium enabled Slovakia to join the EU in 2004, along with seven other Central-Eastern European countries. EU accession caught Slovakia on a trajectory of population aging and demographic decline. The fertility rate was and still stands significantly below the replacement rate, and the old-age dependency ratio is projected to rise to over $60 \%$ by 2060 , marking one of the highest figures among the EU member states (Eurostat 2012). Immigration remains low, standing at around $1 \%$ of the population in $2011^{1}$, and cannot be expected to sufficiently compensate for these demographic trends in the foreseeable future. The labor market still has not fully absorbed the structural imbalances originating from the pre-1989 command economy.

Despite these structural problems, Slovakia's accession to the EU in 2004 marked an era of improving living standards following a sequence of comprehensive economic reforms that the country mainly implemented in the early-2000s. The unemployment rate halved between 2004 and 2008, from 18\% to $9.6 \%$, although it began to rise subsequently as the economic conditions deteriorated during the Great Recession (see Figure 1). Unemployment particularly affects less-skilled workers and the elderly, as well as those living in rural areas (Brožovičová et al. 2013). However, the benefits of economic growth have not trickled down equally, with large regional disparities persisting in Slovakia. In 2004, regional unemployment rates ranged from $8.3 \%$ in Bratislavský region to almost $27 \%$ in Banskobystrický region in central Slovakia (Regional Statistics Database, Slovak Statistical Office). ${ }^{2}$

\footnotetext{
${ }^{1}$ Hlinčíková, Lamačková, and Sekulová (2011)

${ }^{2}$ http://px-web.statistics.sk/PXWebSlovak/index_en.htm
} 
EU accession started a new wave of increased out-migration from the country (see Figure 1). The number of migrants working abroad rose from around 100,000 in 2004 to a peak of 177,000 in 2007 , before sharply falling to around 129,000 by 2009 , with a slow decline and stabilization thereafter. Against the background of the demographic transformations, changing economic asymmetries and the Great Recession in particular, these changes in migration dynamics pose a number of nontrivial questions. Have migration flows cushioned the adverse effects of the economic shocks affecting the Slovak economy during the crisis, absorbing the redundant labor force and relieving the pressure on the Slovak welfare system? Or have they led to a deterioration of the country's stock of human capital due to outflows of the young and educated?

In Slovakia, the relationship between economic growth and labor outflows appears to be positive, with migration on the rise during the period of strong GDP growth between 2004 and 2007, declining during the period of sharp economic slowdown in 2008-2009, and remaining relatively stable during the period of moderate recovery since 2010 . The overall pattern suggests that factors other than economic growth in Slovakia were key determinants of the magnitude of the outflows. On the other hand, recent studies propose that the primary drivers of out-migration include domestic labor market conditions. Besides supply and demand factors, it has been argued that labor market structure and broader institutional infrastructure, including welfare system generosity and targeting, reflect additional factors behind the observed trends (Kureková 2011a; Kureková 2013).

The interaction between unemployment and migration is crucial to the understanding of the possible role of migration as an adjustment mechanism (Puhani 2001; Fidrmuc 2004; Jurajda and Terrell 2009). One hypothesis suggests that it was primarily those with a higher probability of unemployment or inactivity who sought their luck in foreign labor markets, thereby relieving the slacks in the Slovak economy during the downturn. Ideally, these people 
would subsequently acquire additional human capital abroad (relative to the counterfactual of continuing their career, possibly involving spells of unemployment or inactivity, in Slovakia), to the benefit of Slovakia if they returned. Additional effects could arise from remittances, peer effects or direct and indirect supply and demand factors on non-migrant populations. ${ }^{3}$ On the other hand, another alternative is the emergence of a brain drain and other adverse effects of the shrinking labor force in Slovakia on its labor market and welfare systems.

In terms of the observed macro trends, it is necessary to recognize their supply and demand sides. Whereas the deterioration in the Slovak labor market during the Great Recession can be seen as a strong impetus to the supply of necessity-driven migrants from Slovakia, the demand for these workers in some of the key destination countries, including Ireland and the UK, also severely deteriorated. It is most likely the interplay of these supply and demand factors, as well as the changing policy landscape, that drove much of the variation in migration flows.

Empirically, although a causal macro-level relationship for Slovakia has not been empirically established, Pryymachenko, Fregert, and Andersson (2011) found that emigration during 2000-2007 had a strong attenuating effect on unemployment in new member states: a $10 \%$ increase in emigration rate resulted in a decrease in the unemployment rate of around $5 \%$. Given that significant migrant outflows after the accession correlated with a marked decline in unemployment in Slovakia, a similar impact is not implausible for the country. ${ }^{4}$ Correlating labor outflows with unemployment rate between 2004 and 2012 for Slovakia yields a strong negative relationship (see Figure 1, Pearson coefficient $=-0.80$ ) indicating that the attenuating effect of out-migration on the unemployment rate overshadows the push effect of unemployment on migration.

\footnotetext{
${ }^{3}$ For example, Elsner (2013) found significant positive effect on wages of stayers in Lithuania.

${ }^{4}$ However, emigration has not only contributed to a decline in unemployment, it has also exacerbated labor shortages (Rutkowski 2007).
} 
In order to evaluate the effects of the outflows of migrants on the Slovak economy visà-vis the counterfactual of restricted mobility, it is important to consider which groups in the population - such as students, skilled or unskilled workers, or the unemployed - were more likely to decide to migrate, how they compared to their counterparts who did not migrate, how they fared in host labor markets, which of them decided to return, and how those who returned were absorbed in the Slovak labor market. Existing research has argued that profiles of migrants have differed based upon destination countries and key motives for emigration (Kureková 2011b; Bahna 2012a). A large share of people who worked abroad in the years following accession were young and well educated. This suggests that while by reducing labor market tensions migration could serve as an important adjustment mechanism, the possibility of a negative impact owing to brain drain or brain waste cannot be a priori excluded (see also Anacka, Fihel, and Kaczmarczyk 2014, this volume).

In this paper, we seek to assess migration dynamics from Slovakia to the rest of the EU since 2004 in terms of its interaction with the economic and social trajectory of the country and particularly the prospects of brain drain, brain gain and brain circulation. We study the extent to which migration has served as an adjustment mechanism in Slovakia during the Great Recession, including whether it exacerbated or mitigated the effects of the crisis.

We proceed as follows. The next section discusses the available data and its limitations. We subsequently provide an insight into the scale and composition of postenlargement migration flows. In the following section, we turn to an analysis of the determinants of out-migration from Slovakia, discussing whether migrants succeeded abroad, who returned, and with what outcomes. Finally, we explore the role of policies and transitional arrangements, before concluding. 


\section{Data sources and data caveats}

We base our analysis of the selectivity of migrants on the Slovak Labor Force Survey (LFS) data, using both the aggregate statistics and micro-level dataset to measure the determinants of (short-term) labor migration by means of analyzing the main trends and a probabilistic econometric model (Probit). While the LFS is one of the few currently available representative datasets that enables studying out-migration, it has certain limitations. For instance, it only covers short-term migrants who have worked abroad for less than one year and are still considered members of a household resident in Slovakia. It thus does not capture the migration of economically independent units, whether single- or multi-person households. However, individuals engaging in temporary or seasonal work abroad or commuters are considered household members, even if they work abroad for more than a year, and are therefore included in the survey (Bahna 2012c). An important implication of this is that the LFS better captures those migrants who are family members and have attained circular or temporary patterns of mobility. To measure the scale of migration, we also rely on relevant sources in the main destination countries. Data on return migrants is not readily available and thus we infer return based on the interpretation of the changes in trends in immigration and out-migration to and from Slovakia and the main receiving countries. We use administrative data from the Central Labor Office to describe aspects of the labor market integration of return migrants.

\section{Scale of migration and its composition}

\section{Scale of migration}

Labor migration from Slovakia has been sizable during its transformation and particularly after its accession to the EU (Figure 1). ${ }^{5}$ The number of workers abroad rose

\footnotetext{
${ }^{5}$ For similar but slightly different data on migration stock and flows see Holland et al. (2011). See also Kahanec, Pytlikova, and Zimmermann (2014, this volume).
} 
sharply between 2004 and 2007, when it peaked at 177,000 people. ${ }^{6}$ However, due to the data limitations presented above, this number is likely to be underestimated. Experts have estimated that approximately 230,000-250,000 workers were employed abroad (mostly EU countries) in 2007 (Gelvicka 2009), equaling approximately one tenth of the active labor force (10-12\%) (own calculations, active labor force based on Eurostat data). Between 2007 and 2009, the number of Slovaks working abroad declined considerably, before leveling off at circa 120,000 thereafter. We believe that the decline in the number of labor migrants since 2007 represents both the return of those who had worked abroad and a lower rate of outflows (see also Zaiceva and Zimmermann 2014, this volume). By the end of 2012, the overall number of labor migrants had not fallen to the pre-accession levels, suggesting that European labor markets continue to be an important destination for Slovaks. It also indicates that despite worsening economic performance in most destination countries Slovak workers cope with the relatively high rate of unemployment in Slovakia by continuing to work abroad.

Emigration from Slovakia has been unbalanced across regions. This is documented in Figure 2, showing a large variation in the share of emigrants in the economically active population by regions. The lowest and relatively stable share of outflows was found from Bratislava region, while the highest outflows took place from the regions of Prešov, Nitra and Žilina. These figures are closely correlated with regional labor market conditions and structural deficiencies that have been found to have affected patterns of emigration in Slovakia (Kureková 2011b).

\footnotetext{
${ }^{6}$ For limitations of the ability of LFS to capture migration see (Bahna 2012c).
} 
Figure 1. Labor migration and economic indicators: 2004-2012

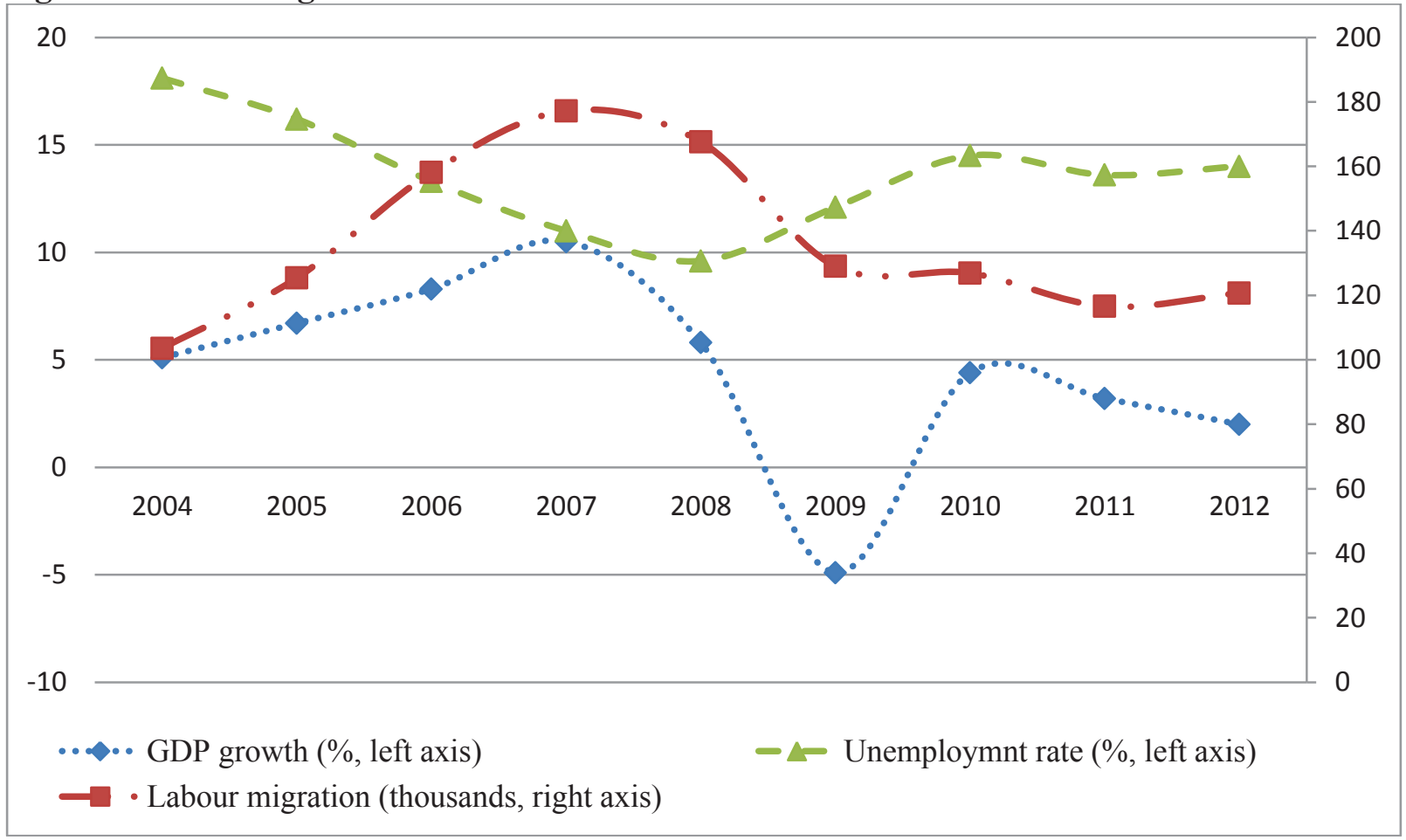

Source: Labor migration (stock): Slovak Statistical Office based on the Labor force survey; GDP growth and unemployment rate: Eurostat.

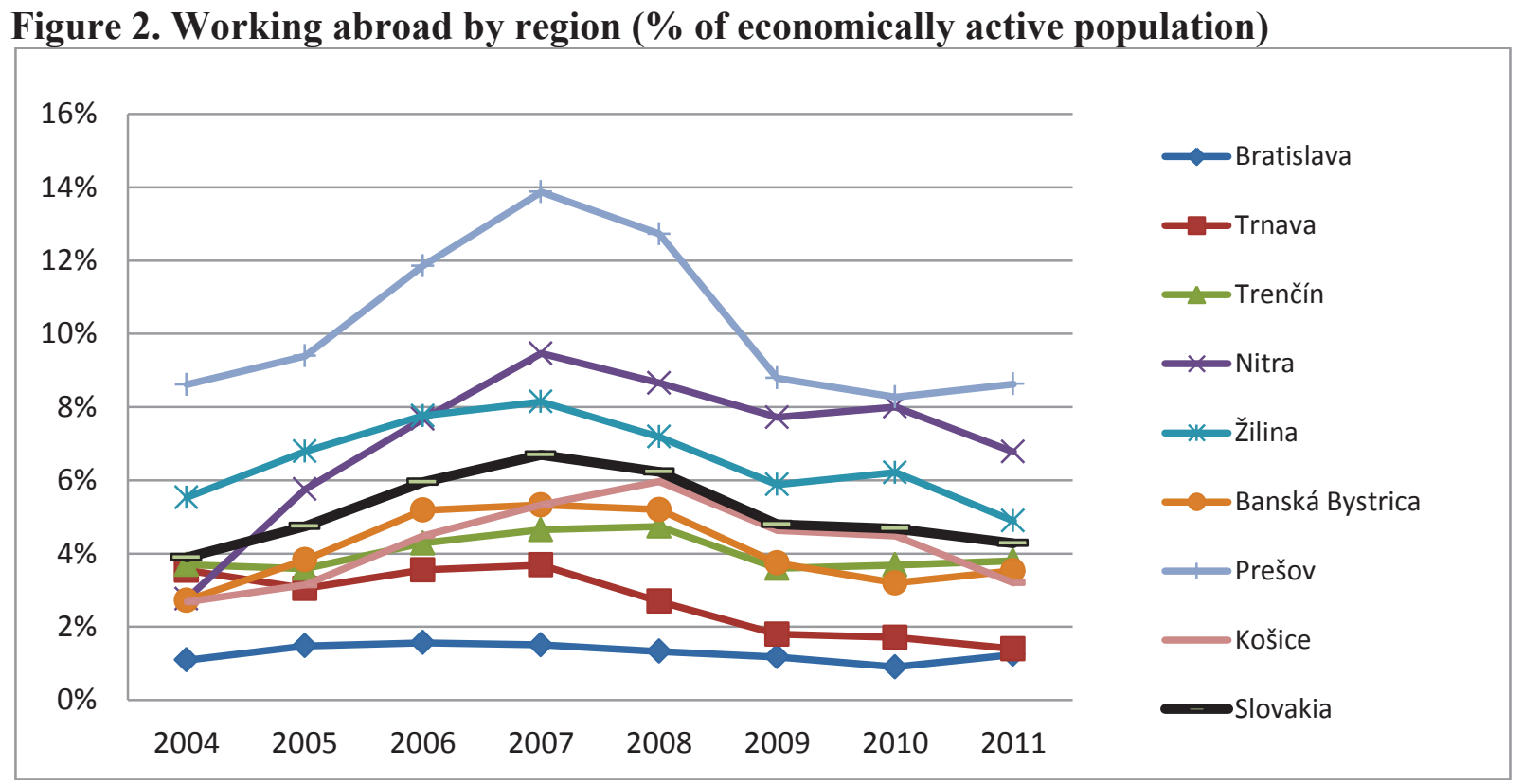

Source: Slovak Statistical Office, LFS. Own calculations.

\section{Destination countries}

The aggregate figures presented above mask important compositional aspects of labor migration, changes in migrant profiles and shifts in destination countries over time. The 
interaction of host and home country labor market conditions in terms of the directionality, composition and, indeed, magnitude of migration flows is crucial for understanding the role of migration for Slovak and EU labor markets.

Since 2004, a diversification of flows to different destination countries has occurred (Figure 3). The crisis and the way in which it affected Slovak migrants' selection of destination countries is reflected in the structure of the flows. While the Czech Republic has remained the main destination country for Slovaks, the number and share of migrants heading there in proportion to other destinations has declined over time (from over $60 \%$ in 2004 to just over $40 \%$ by 2012$).{ }^{7}$ Post-accession emigration to the UK, Ireland and Hungary rose significantly, but the stocks declined approximately to 2004 levels by 2012 . This decline is probably the result of the economic deterioration in these receiving countries' labor markets.

Figure 3. Working abroad by destination country

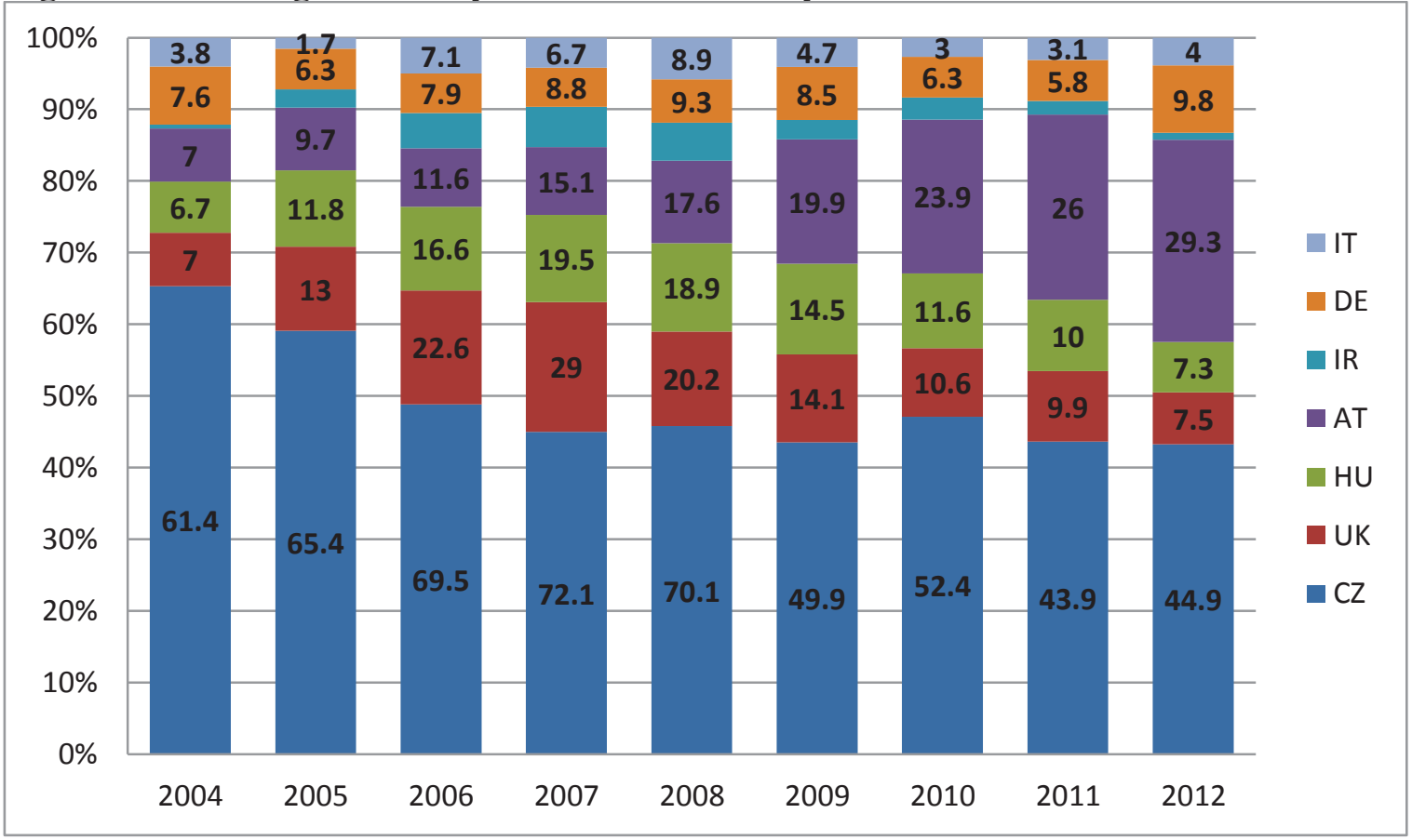

Notes: in per cent, numbers reported in the diagram represent the number of migrants in thousands. Legend: IT - Italy, DE - Germany, IR - Ireland, AT - Austria, HU - Hungary, UK - United Kingdom, CZ - Czech Republic.

Source: Slovak Statistical Office, LFS.

\footnotetext{
${ }^{7}$ Bahna (2012a) argues that one of the reasons behind the decline might be due to the way LFS data is collected whereby long-term emigrants are not considered members of the household anymore and are therefore not counted.
} 
It is useful to compare the LFS data with the registry data from the UK (NINO) ${ }^{8}$ and Ireland (PPSN) ${ }^{9}$ (Figure 4). NINO and PPSN figures can be considered the most accurate measure of the new arrivals (i.e. inflows) from Slovakia who are employed legally, i.e. paying taxes and social security contributions. Data reveals that the number of new arrivals in the UK halved between 2007 and 2009 and in Ireland between 2006 and 2008. Comparing these figures to the LFS data, which in turn measures the number of migrants currently employed abroad (but only for less than one year and if considered members of stayers' household), we observe that the numbers closely follow registration trends.

Figure 4. Immigration of Slovaks to the UK and Ireland

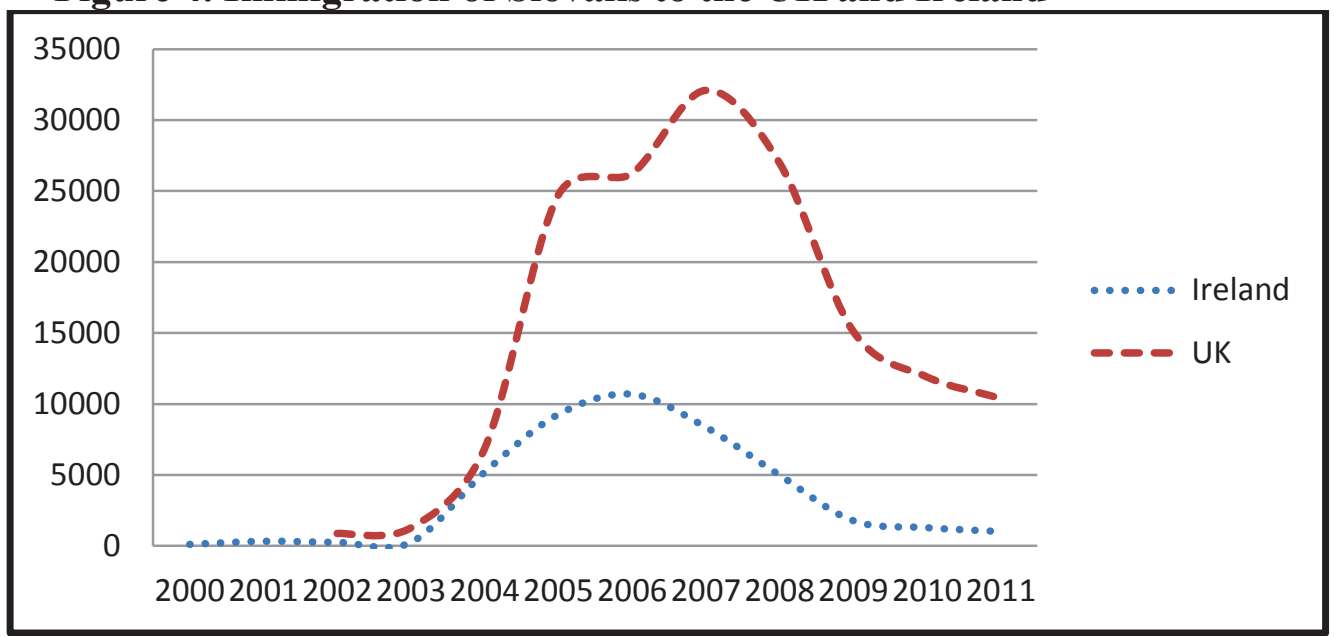

Source: PPSNs - Ireland, NINO - UK.

The flow of Slovak migrants to Austria shows a rising trend. Migration continued to grow despite transitional arrangements in place until May 2011. This was in part due to legal adjustment in the social and personal care sector in Austria, where the authorities responded to the mutual supply-demand interest in the migrant labor by gradually legalizing and regularizing Slovak women working in Austria since 2006 (Bahna 2012b). Looking at this phenomenon empirically, Bahna (2012b) explicitly tests the competing hypotheses of the 'crisis effect' versus the 'legalization effect', combining LFS data with his own data collection. He argues that decisions to undertake care work in Austria, as well as the level of

\footnotetext{
${ }^{8} \mathrm{http} / / /$ statistics.dwp.gov.uk/asd/asd1/niall/data_collection.pdf

9 http://www.welfare.ie/EN/Topics/PPSN/Pages/ppsstat.aspx
} 
income of care workers are to a greater extent explained by personal characteristics of care workers and structural factors in Slovakia, rather than the recent Austrian legislation policies. While the increase in the numbers of Slovak care workers occurred a year after the legalization in Austria, it also strongly coincided with the rise in unemployment induced by the crisis. Care workers who came to Austria after 2008 were more often previously unemployed and from regions of Slovakia with high unemployment (ibid). This indicates that both legal frameworks and socio-economic developments played a role in shaping outmigration patterns to neighboring Austria.

A similar increase did not occur with respect to out-migration to Germany, where a relatively stable share of Slovak migrants went during the studied period (Figure 3). We observe two peaks of migration to Germany: one in 2008-2009 and another in 2012. The first one may signal adjustment of migration flows in response to the deteriorating economic situation in Slovakia and in other destination countries such as Ireland or the UK at the onset of the Great Recession. The latter peak is probably due to the end of transitional arrangement in May 2011. Despite strong demand for social care labor in Germany, Slovak female workers appear to prefer fortnightly commuting to neighboring Austria (Bahna 2012b).

\section{Demographic characteristics and shifts}

The composition of those working abroad is strongly biased towards males, who comprise around $70 \%$ of all outflows. However, a more detailed analysis of gender composition by destination countries shows that groups of countries of destination have attracted males and females differently (Figure 5). Most migrant workers going to the UK, Ireland and Sweden prior to accession in 2003 were females, although the balance has since 
reversed over time. ${ }^{10}$ Austria and Germany have attracted a growing share of female workers since 2007, mainly drawn into the elderly and social care sector. Although micro-level evidence is not yet available, this might signify a shifting role of middle-aged and elderly women during the Great Recession, who may have assumed a bread-winner position in their households, as male migrants faced difficulties in construction or manufacturing in the UK, Ireland or the Czech Republic. Indeed, migration to Austria and Germany is negatively correlated with that to Ireland, Sweden, the UK, near EU12 and other EU countries (Figure 5).

Figure 5. Gender structure by destination groups: share of females

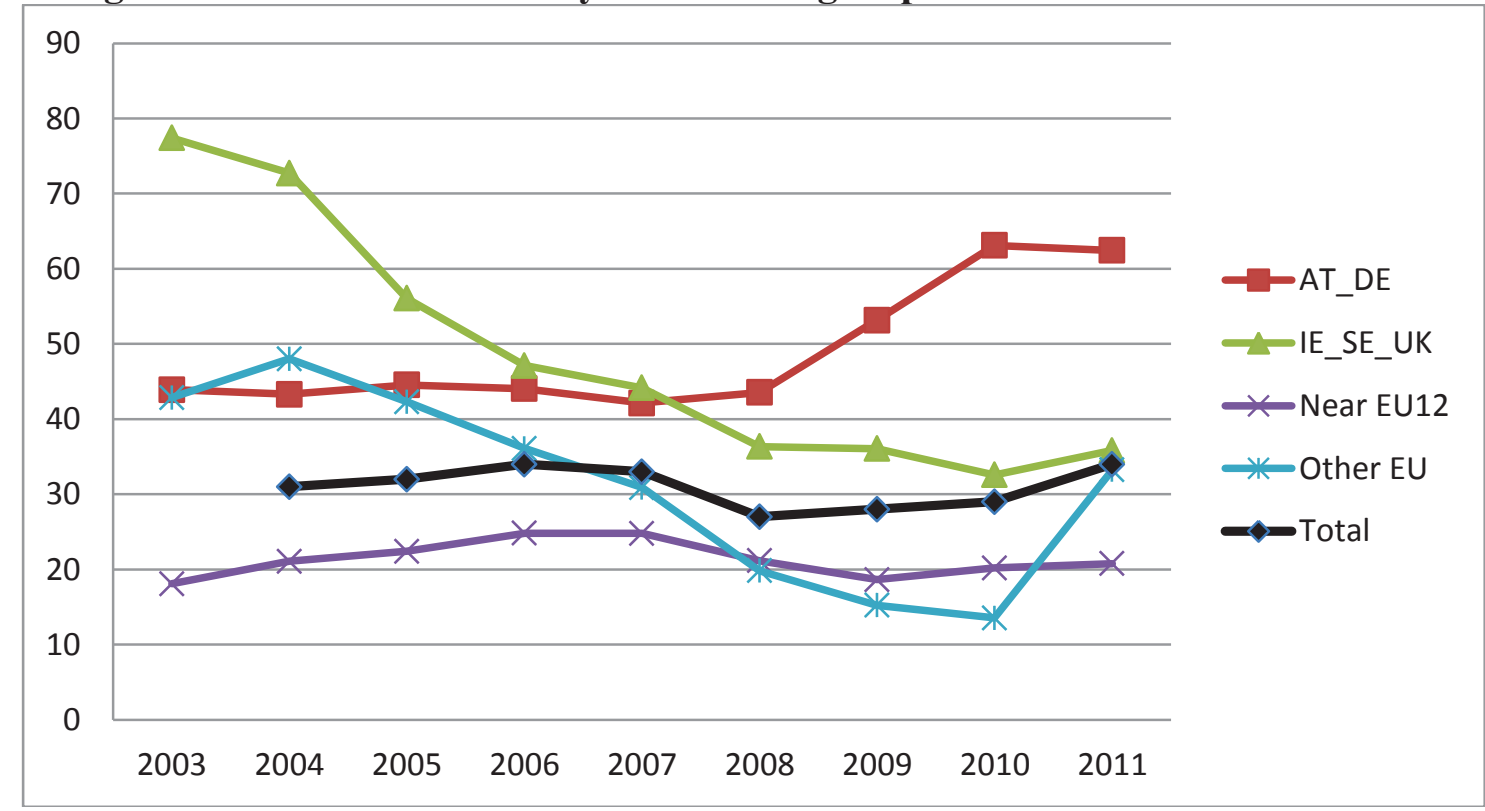

Notes: In per cent.

Legend: AT - Austria, DE - Germany; IE - Ireland, SE - Sweden, UK - United Kingdom; Near EU12 - Czech Republic, Hungary and Poland; Other EU - Belgium, Bulgaria, Cyprus, Denmark, Estonia, Finland, France, Greece, Italy, Latvia, Lithuania, Luxembourg, Malta, Netherlands, Portugal, Romania, Slovenia, and Spain, also including EFTA countries Island, Norway and Switzerland.

Source: LFS, own calculations.

Corresponding to the shift in destination countries, a change in the composition of migrants by age groups is also evident (Figure 6a). While between one-third and a quarter of migrants were 15-24 years old in early post-accession years, their contribution to the outflows

\footnotetext{
${ }^{10}$ This could be due to the fact that prior to accession, especially the UK was open towards migration of females to work as au-pairs (see for example Williams and Baláz 2004; Williams and Baláž 2005). See also Gerdes and Wadensjö 2014, this volume).
} 
had declined significantly by 2011. On the other hand, the outflow of 35-44 and especially 4554 and 55+ cohorts significantly increased since the beginning of the Great Recession.

These trends are consistent with the changing nature of out-migration from Slovakia: whereas students and fresh graduates seeking foreign experience and going mainly to Ireland and the UK dominated shortly after accession, the Great Recession appears to have triggered outflows of aged workers primarily to Austria and Germany. The youth is much less inclined to migrate to closer destinations, which are relatively preferred by older workforce (Figures $6 \mathrm{~b}, 6 \mathrm{c})$. While these trends might be partly due to migrants' aging, as well as other factors such as the dissolution of migrants' ties to households in Slovakia, they indicate significant changes in Slovaks' migration patterns after the country's EU accession and during the Great Recession.

Interestingly, this shift in the age structure is not necessarily reflected in the shift in the emigrants' education composition (Figure 7). Over $80 \%$ of emigrants at any point in time had higher secondary education (with (upper-secondary) or without (lower-secondary) leaving certificate). Higher secondary level is the predominant educational attainment for higher age categories in Slovakia; however, this is not the case for the youth, as the massification of higher education in late-1990s and 2000s has resulted in a steeply increasing share of university graduates. The fact that (i) the age composition of migrants was changing significantly, (ii) the educational composition of young cohorts in Slovakia increased markedly and yet (iii) the educational composition of migrants was not changing much signals that the trend of an increasing educational attainment of the source population was attenuated by a decreasing share of young people among migrants. This also indicates that educational attainment and age have correlated effects on the selectivity of migrants; i.e. that the effect of educational attainment on out-migration changes with age. 
Figure 6. Age composition of emigrants

\section{a) All destinations}

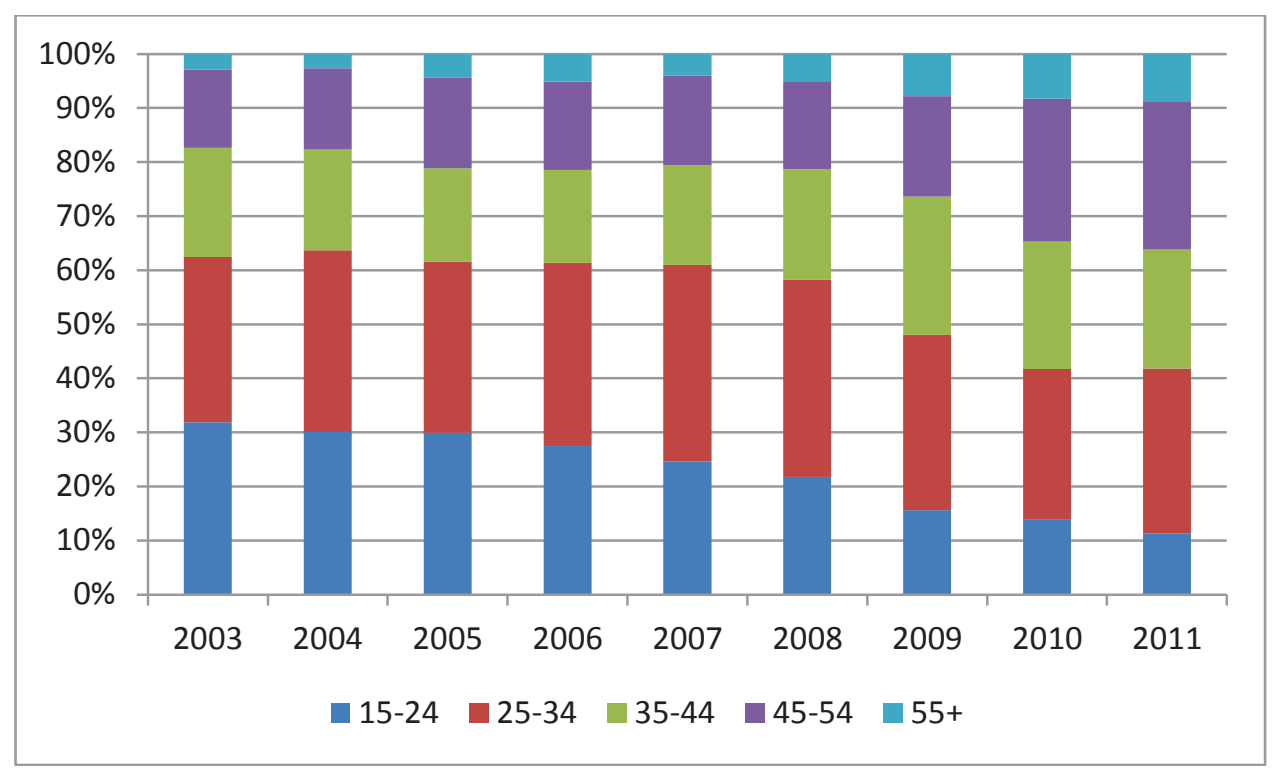

b) Austria and Germany

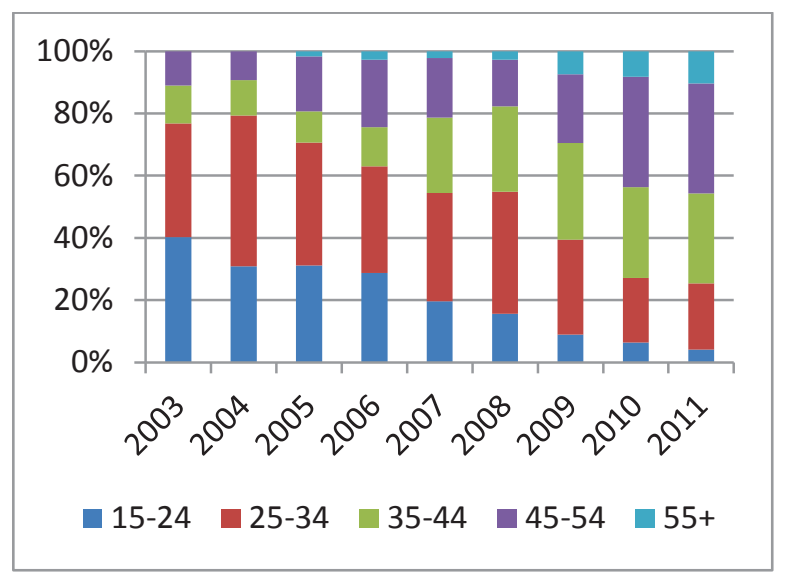

c) Ireland, Sweden and UK

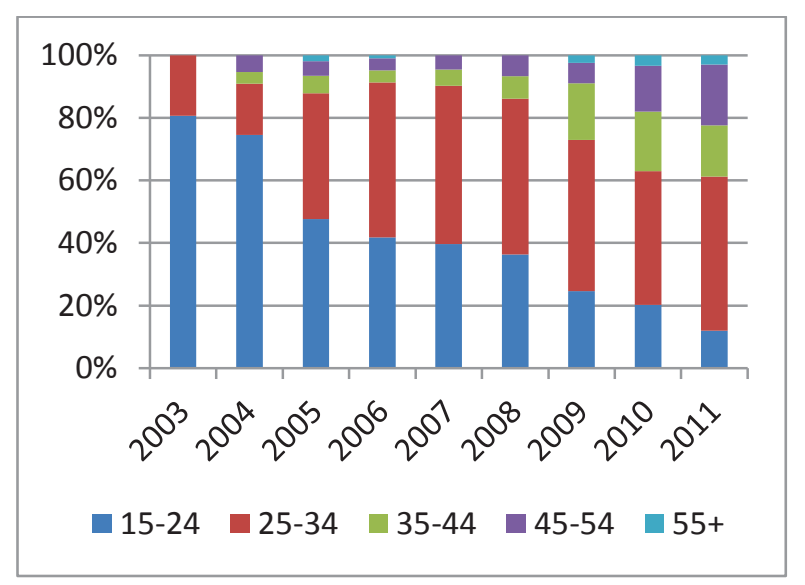

Source: LFS, own calculations.

Even at the height of migration to the UK and Ireland, the share of tertiary educated migrants was low, which could be due to a large fraction of young people who were still in education going to work abroad during summer breaks among the migrants. A further reason could be the undercounting of high-skilled migrants in the LFS if they were considered as independent economic units. 
Figure 7. Education composition of emigrants

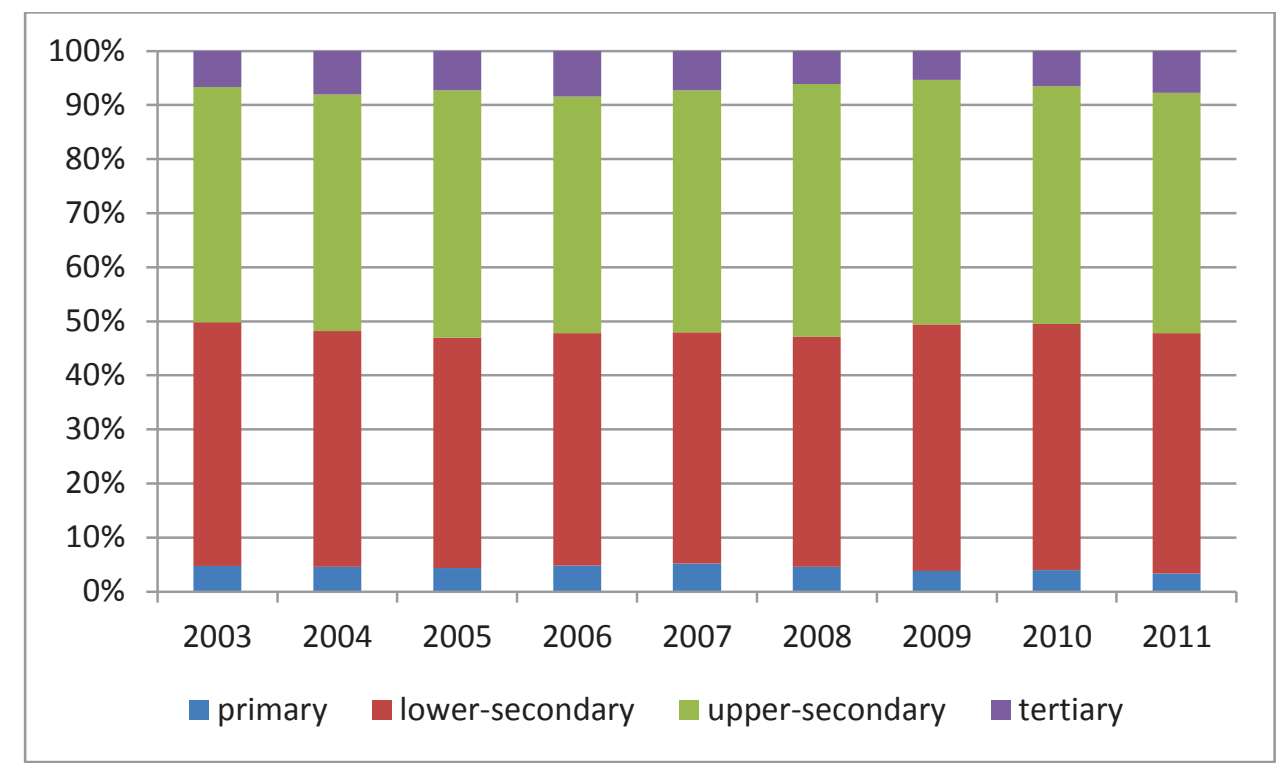

Source: LFS, own calculations.

The composition of out-migration by occupation in the destination country documents a somewhat fluctuating but rather trend-less share of migrants working in low-skilled elementary occupations (ISCO9) (Figure 8). The share of plant and machine operators and assemblers (ISCO 8) has been increasing until 2008 when it reached more 21.2\%, since when it declined down to $14.9 \%$ in 2011 . The share of migrants in ISCO 7 jobs (craft and related trade jobs) had been declining until 2007, since when it stabilized or somewhat increased. The service sector (ISCO5), which includes personal care workers, had been rather stable before the onset of the Great Recession, during which it increased from $15.2 \%$ in 2008 to $22.3 \%$ in 2011. The share of migrants in highly skilled occupations (ISCO 1+2, but also ISCO 3) was somewhat higher before than during the Great Recession, although in 2011 the share of migrants in the two highest ISCO categories increased back to almost the pre-recession levels. In panels $\mathrm{b}$ and $\mathrm{c}$ we observe that the overall trends mask important reallocation across destination countries: whereas in Austria and Germany the service and sales sector was losing importance until the onset of, and gained importance through, the Great Recession at the expense of most of the other sectors, in Ireland, Sweden and the UK the decline of the service 
and sales sector continued during the Great Recession. As we see from the discussion above, the beginning of the Great Recession was a noteworthy turning point for several trends.

Figure 8. Working abroad by occupation

\section{a) All destinations}

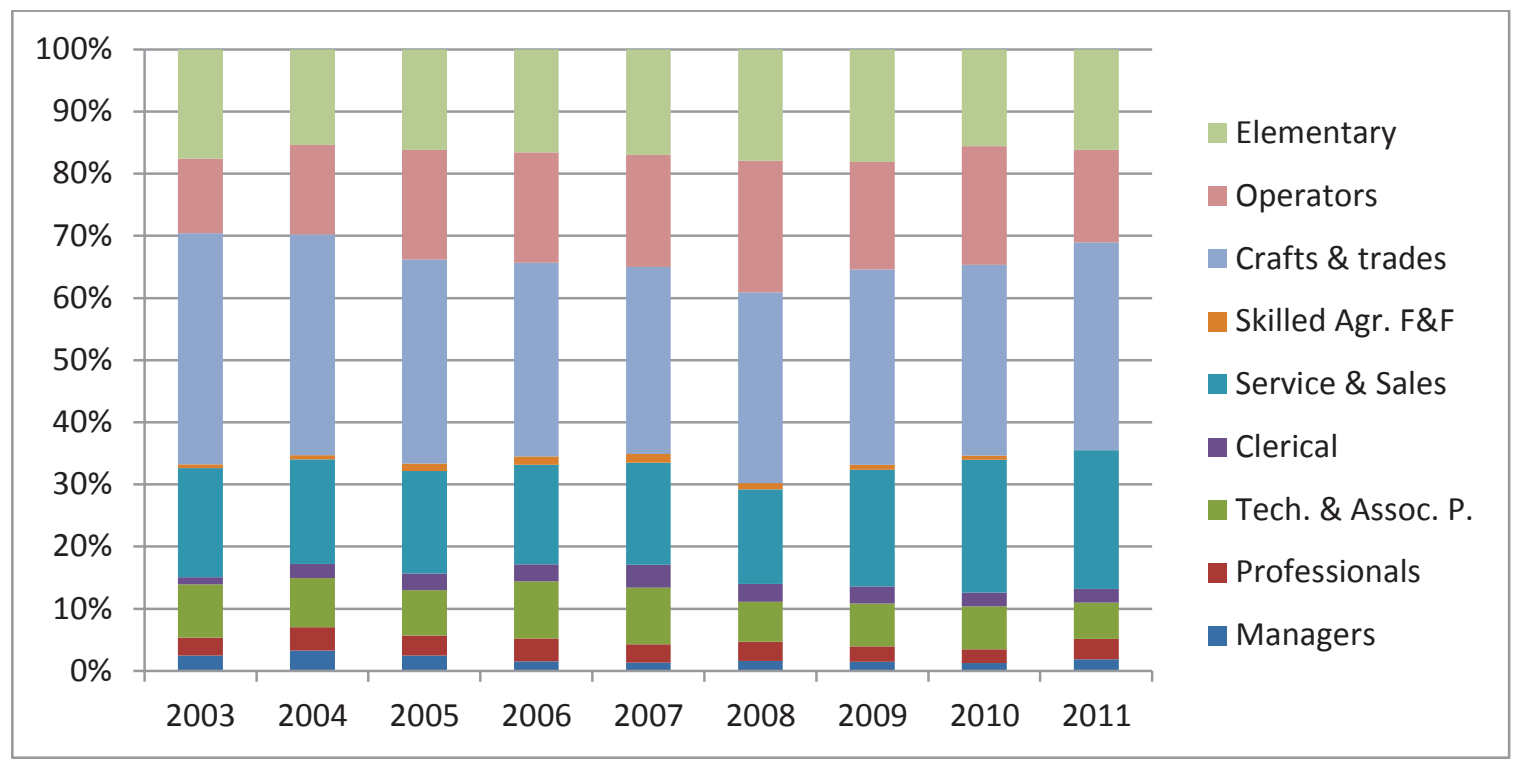

b) Austria and Germany

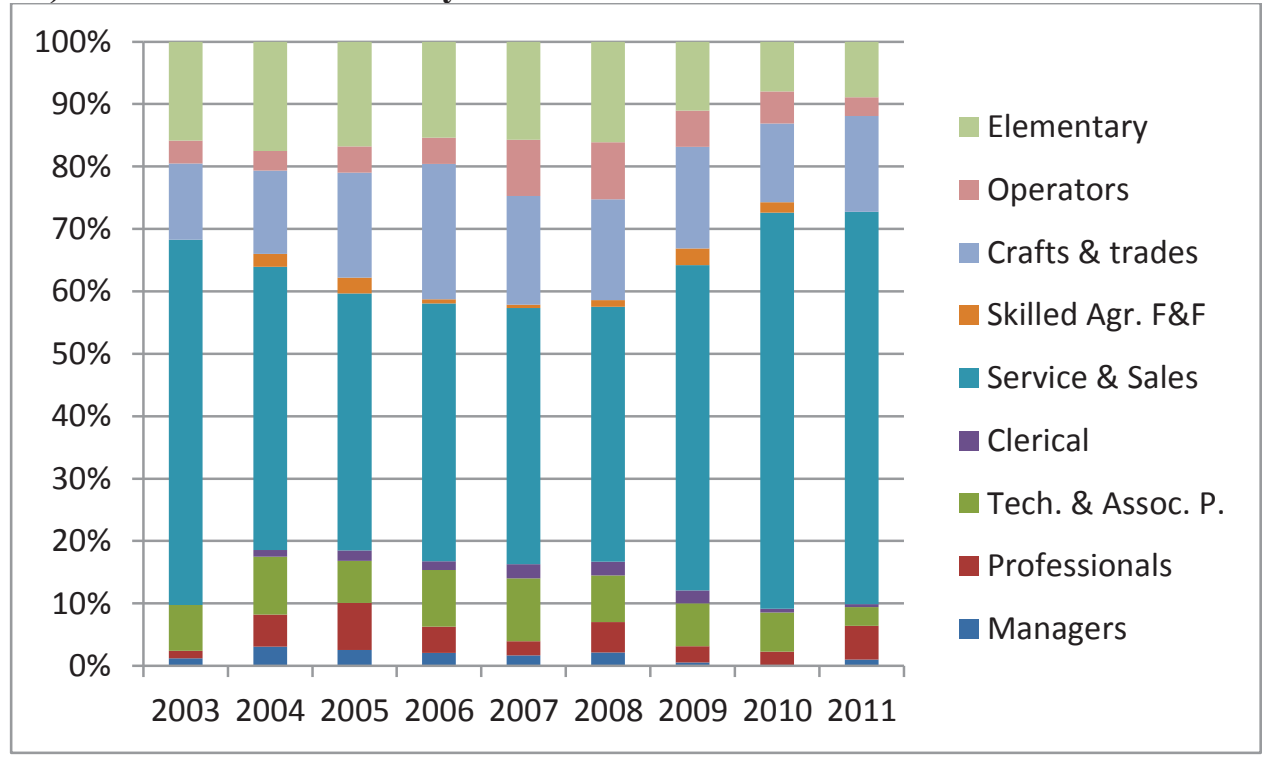




\section{c) Ireland, Sweden and UK}

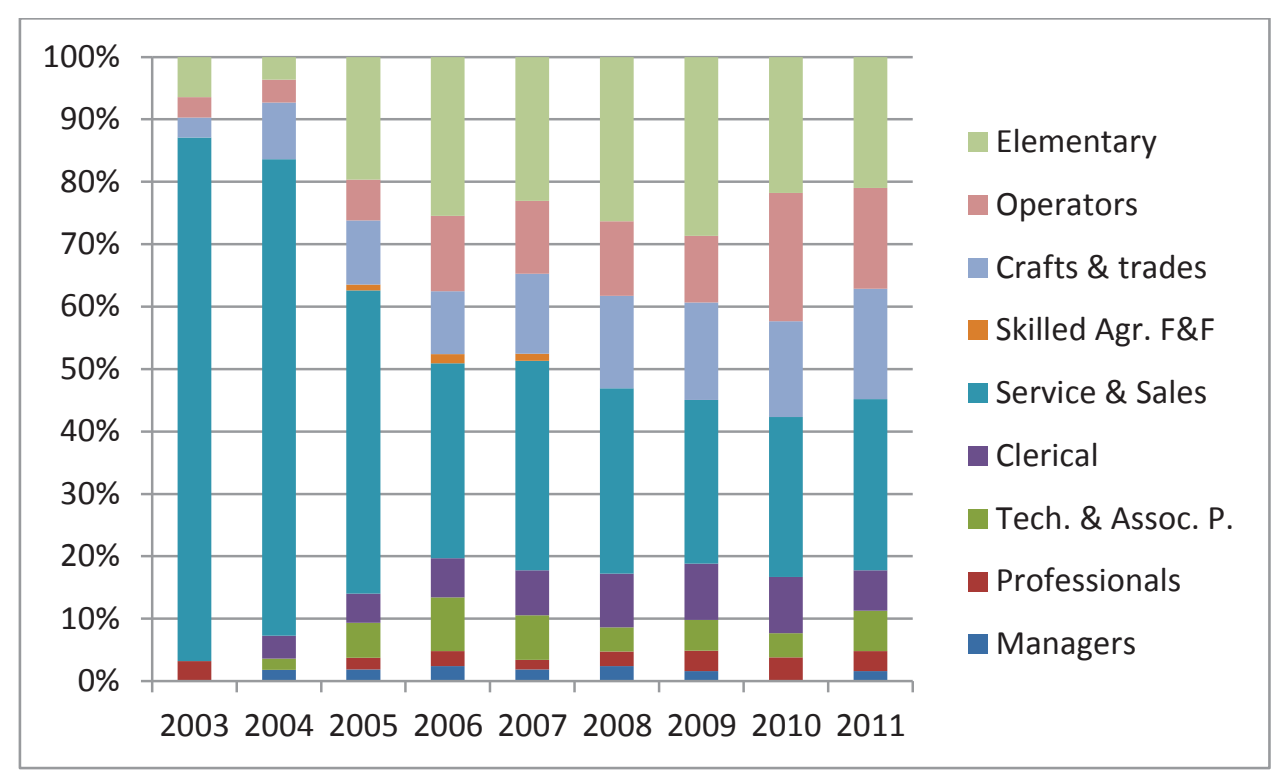

Source: LFS, own calculations.

\section{The determinants of mobility}

In this section, we expand the analysis of main migration trends to study the selectivity of the intra-EU mobility of Slovaks. We measure the independent effects of a number of key variables, including age, gender, ethnicity, economic status, educational attainment, field of study and region of origin, using a parsimonious regression analysis of data from the Slovak Labor Force Survey (see Fertig and Schmidt 2001; Hatton 2005; or Kahanec, Pytlikova, and Zimmermann 2014, this volume, for structural approaches). We explore the development of key determinants over time and in relation to the Great Recession. We also specifically study the determinants of migration of the youth. Table 1 presents a baseline model for a sample of all people aged 15 or over (Model A) and a model extended to account for economic status and field of education, run on a sub-sample of people for whom this information was nonmissing (Model B) and for youth (a sub-sample aged 15-24) specifically (Model C), based on a pooled dataset covering the period from 2003-2011. Table 2 reports the results from the full model for each year separately. 
The models produce consistent and robust results across different specifications. One general finding is that the region of origin and year have the most substantial impact on migration propensity. Compared to affluent Bratislava, residing in less economically developed regions in Slovakia increases the migration probability by as much as $16 \%$ in the case of Prešovský region in the eastern part of Slovakia. The year effect increases up until 2007-2008 and subsequently rises again in 2010 (Model A and Model B). These variables jointly proxy the labor market conditions and general situation across the regions in Slovakia and over time, as well as picking up the year-fixed effects of, inter alia, the economic development and the liberalization or abolition of transitional arrangements in receiving labor markets.

While demographic variables matter, individually they appear less important than the region of origin impact. As expected, migration propensity declines with age and is lower for females. Being married, as well as being divorced or widowed, also reduces the propensity to migrate. Having children in the household has a different effect on men and women: while men with children are significantly more likely to migrate, such an effect is not present for females. Compared to Slovak nationals, ethnic minorities are more likely to work abroad, which is specifically evident for the Roma. ${ }^{11}$

Importantly, migration propensity decreases with educational attainment. On the other hand, only selected fields of study have an impact of migration: having majored in education, social sciences and agriculture reduces and health and social work major increases the likelihood of working abroad.

In order to evaluate the effect of economic status on the propensity to work abroad, we consider the situation of individuals one year before the survey. Compared to those employed one year ago, those who were unemployed or university students are significantly more likely

\footnotetext{
${ }^{11}$ Ethnicity measured as a self-identified variable. This may be problematic especially for the Roma, for whom ethnic self-identification tends to differ between national surveys and focused surveys (Zimmermann et al. 2008).
} 
to work abroad. This is consistent with the findings of other studies, which have argued that two distinct profiles of migrants from Slovakia were formed after the accession (Kureková 2011b): youth migrants mainly going to the new destinations (UK, Ireland) with short-term motives and not necessarily due to unemployment reasons; and more mature migrants who migrated to geographically closer destinations, were breadwinners, married and previously unemployed. These results are also consistent with those reported by Kahanec and Fabo (2013), who studied intentions to migrate from new member states.

Model C presents results for the youth (aged 15-24), revealing some important differences with respect to the general working age population. Among the youth, females are $3 \%$ more likely to work abroad than males, while being Roma increases the likelihood by a staggering $36 \%$. Having studied health or social work increases the propensity to migrate by $9 \%$, whereas other fields of study do not have a statistically significant effect. Young unemployed are pushed out by almost 5\% more than their employed counterparts. The peak of youth work migration was in 2006 and 2007, with migration propensities having subsequently declined. The region of origin has a very large impact, significantly stronger than among the general population. Specifically, young people from Prešovský, Košický and Banskobystrický regions are $43 \%, 26 \%$ and $28 \%$ more likely to work abroad than the youth from the Bratislava region. 
Table 1. Probability of working abroad, 2003 - 2011

\begin{tabular}{|c|c|c|c|}
\hline & $\begin{array}{l}\text { Model A } \\
\text { Baseline } \\
\end{array}$ & $\begin{array}{c}\text { Model B } \\
\begin{array}{c}\text { Economic status and } \\
\text { education field }\end{array} \\
\end{array}$ & $\begin{array}{l}\text { Model C } \\
\text { Youth } \\
(15-24) \\
\end{array}$ \\
\hline \multicolumn{4}{|c|}{ DEMOGRAPHIC CHARACTERISTICS } \\
\hline Female & $\begin{array}{c}-0.0130 * * * \\
(0.00112)\end{array}$ & $\begin{array}{c}-0.00760 * * * \\
(0.00127)\end{array}$ & $\begin{array}{c}0.0308 * * * \\
(0.00722)\end{array}$ \\
\hline Age: $25-34$ & $\begin{array}{c}-0.0169 * * * \\
(0.00115)\end{array}$ & $\begin{array}{c}-0.0106 * * * \\
(0.00128)\end{array}$ & \\
\hline Age: $35-44$ & $\begin{array}{c}-0.0269 * * * \\
(0.00123)\end{array}$ & $\begin{array}{c}-0.0223 * * * \\
(0.00132)\end{array}$ & \\
\hline Age: $45-54$ & $\begin{array}{c}-0.0289 * * * \\
(0.00135)\end{array}$ & $\begin{array}{c}-0.0236 * * * \\
(0.00142)\end{array}$ & \\
\hline Age: $55+$ & $\begin{array}{c}-0.0297 * * * \\
(0.00105)\end{array}$ & $\begin{array}{c}-0.0242 * * * \\
(0.00120)\end{array}$ & \\
\hline Married & $\begin{array}{c}-0.0351 * * * \\
(0.00174)\end{array}$ & $\begin{array}{c}-0.0327 * * * \\
(0.00176)\end{array}$ & $\begin{array}{c}-0.0728 * * * \\
(0.00619)\end{array}$ \\
\hline Other & $\begin{array}{c}-0.0150 * * * \\
(0.00149)\end{array}$ & $\begin{array}{c}-0.0151 * * * \\
(0.00142)\end{array}$ & $\begin{array}{l}-0.0364 \\
(0.0361)\end{array}$ \\
\hline Child1 & $\begin{array}{l}0.0118 * * * \\
(0.00172)\end{array}$ & $\begin{array}{l}0.0109 * * * \\
(0.00169)\end{array}$ & $\begin{array}{l}0.0186^{*} \\
(0.0102)\end{array}$ \\
\hline Child 2 & $\begin{array}{l}0.0208 * * * \\
(0.00238)\end{array}$ & $\begin{array}{l}0.0188 * * * \\
(0.00233)\end{array}$ & $\begin{array}{c}0.0698 * * * \\
(0.0247)\end{array}$ \\
\hline Child 3 or more & $\begin{array}{l}0.0298 * * * \\
(0.00441)\end{array}$ & $\begin{array}{l}0.0273 * * * \\
(0.00438)\end{array}$ & $\begin{array}{l}0.0870 * \\
(0.0451)\end{array}$ \\
\hline Child $1 \times$ Female & $\begin{array}{c}-0.0190 * * * \\
(0.00150)\end{array}$ & $\begin{array}{c}-0.0190 * * * \\
(0.00144)\end{array}$ & $\begin{array}{l}-0.0118 \\
(0.0129)\end{array}$ \\
\hline Child $2 \times$ Female & $\begin{array}{c}-0.0305 * * * \\
(0.00108)\end{array}$ & $\begin{array}{c}-0.0293 * * * \\
(0.00101)\end{array}$ & $\begin{array}{c}-0.0596 * * * \\
(0.0136)\end{array}$ \\
\hline Child 3 and more $x$ Female & $\begin{array}{c}-0.0327 * * * \\
(0.00106)\end{array}$ & $\begin{array}{c}-0.0304 * * * \\
(0.000939)\end{array}$ & $\begin{array}{l}-0.0489 \\
(0.0331)\end{array}$ \\
\hline ETHICITY & & & \\
\hline Czech & $\begin{array}{c}0.0273 * * \\
(0.0127)\end{array}$ & $\begin{array}{c}0.0381 * * * \\
(0.0147)\end{array}$ & $\begin{array}{c}0.267 \\
(0.220)\end{array}$ \\
\hline Hungarian & $\begin{array}{c}0.0248 * * * \\
(0.00236)\end{array}$ & $\begin{array}{c}0.0171 * * * \\
(0.00227)\end{array}$ & $\begin{array}{c}0.0274 * * \\
(0.0121)\end{array}$ \\
\hline Ukrainian or Ruthenian & $\begin{array}{c}0.0274 * * \\
(0.0109)\end{array}$ & $\begin{array}{c}0.0218 * * \\
(0.0106)\end{array}$ & $\begin{array}{l}-0.0339 \\
(0.0382)\end{array}$ \\
\hline Roma & $\begin{array}{l}0.0247 * * * \\
(0.00862)\end{array}$ & $\begin{array}{c}0.0511 * * * \\
(0.0155)\end{array}$ & $\begin{array}{c}0.362 * * * \\
(0.107)\end{array}$ \\
\hline Other & $\begin{array}{l}-0.00945 \\
(0.0108)\end{array}$ & $\begin{array}{l}0.00145 \\
(0.0138)\end{array}$ & \\
\hline $\begin{array}{l}\text { ECONOMIC STATUS } \\
\text { Non-university student }\end{array}$ & & $\begin{array}{c}0.00277 \\
(0.00409)\end{array}$ & $\begin{array}{l}-0.00158 \\
(0.00945)\end{array}$ \\
\hline University student & & $\begin{array}{c}0.0293 * * * \\
(0.00728)\end{array}$ & $\begin{array}{l}0.00667 \\
(0.0187)\end{array}$ \\
\hline Housewife, parental leave & & $\begin{array}{c}-0.0126 * * * \\
(0.00301)\end{array}$ & $\begin{array}{c}-0.0935^{* * *} \\
(0.00635)\end{array}$ \\
\hline Pensioner & & $\begin{array}{c}-0.0190 * * * \\
(0.00340)\end{array}$ & \\
\hline Unemployed & & $\begin{array}{l}0.0332 * * * \\
(0.00289)\end{array}$ & $\begin{array}{l}0.0491 * * * \\
(0.00924)\end{array}$ \\
\hline Other & & $\begin{array}{l}-0.000288 \\
(0.00716)\end{array}$ & $\begin{array}{l}-0.0108 \\
(0.0216)\end{array}$ \\
\hline
\end{tabular}


EDUCATIONAL ATTAINMENT

Maturita (High-school exit exam)

University degree (BA, MA,

$\mathrm{PhD}$ )

\section{FIELD OF STUDY}

Pedagogy

Social sciences, economics and law

Informatics and natural sciences

Technical sciences and construction

Agriculture and veterinary

science

Health and social work

Services

\section{REGION OF ORIGIN}

Trenčiansky region

Trnavský region

Nitriansky region

Žilinský region

Banskobystrický region

Prešovský region

Košický region

Observations

$\begin{array}{cc}-0.00977 * * * & 0.000742 \\ (0.000960) & (0.00610) \\ -0.0239 * * * & -0.0341 * * * \\ (0.00107) & (0.0124) \\ & \\ -0.0151 * * * & 0.0341 \\ (0.00299) & (0.0349) \\ -0.00859 * * & 0.0214 \\ (0.00335) & (0.0252) \\ -0.000357 & 0.0201 \\ (0.00491) & (0.0340)\end{array}$

$-0.00210$

0.0345

$(0.00383)$

(0.0232)

$-0.00910^{* * *}$

0.0454

$(0.00327)$

$0.0127 * *$

(0.0319)

$(0.00541)$

$0.0946 * *$

$(0.0392)$

0.0226

(0.0259)

(0.00370)

$0.147 * * *$

(0.0278)

$0.212^{* * *}$

(0.0305)

$0.313^{* * *}$

(0.0341)

$0.248 * * *$

(0.0283)

$0.285^{* * *}$

(0.0325)

$0.438^{* * *}$

(0.0287)

$0.266^{* * *}$

(0.0302)

12,543

Notes: Marginal effects; reference categories: male, age 15- 24 (except Model C), single, no children, Slovak ethnicity, employed, education below maturita (High-school exit exam), field of study: humanities, arts or general programs, Bratislavský region; year-fixed effects. Standard errors in parentheses: $* * * \mathrm{p}<0.01, * * \mathrm{p}<0.05, * \mathrm{p}<0.1$.

Source: Slovak LFS (repeated cross-section), own calculations. 


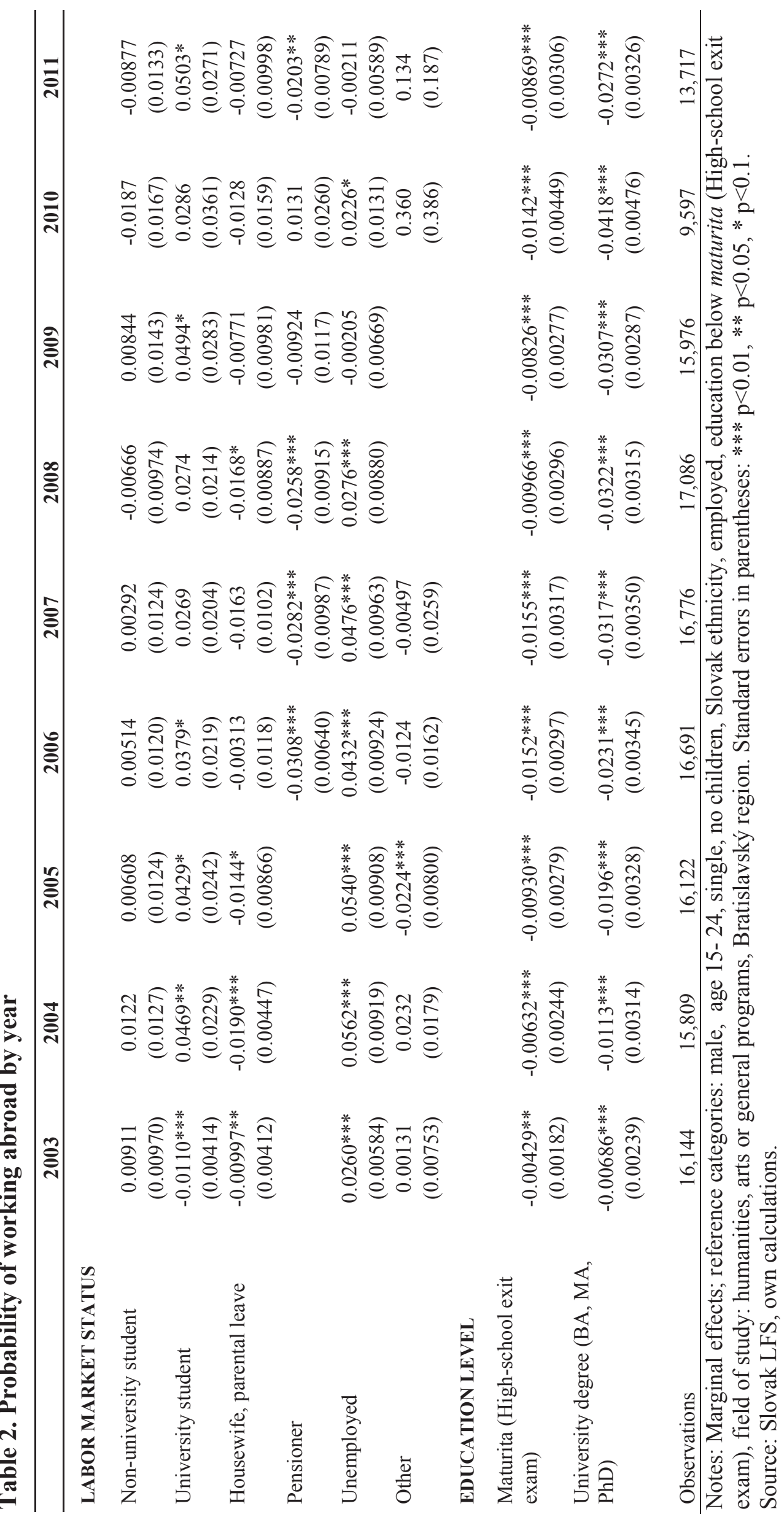


Table 2 presents a set of regressions corresponding to Model B from Table 1 for each year separately. We find consistent results for the impact of basic demographic variables, as presented above, and therefore only display the key variables of interest. ${ }^{12}$ These suggest that for most years, females, older or married persons are less likely to migrate for work abroad. While university students were less likely to migrate than employees in 2003 , this has changed markedly after accession. At the same time, university educated people are significantly less likely to migrate for work in any studied year, and increasingly less so over time, apart from in 2011. With the exception of 2009 and 2011, people who were unemployed a year ago are significantly more inclined to work abroad, although the measured percentage point impact decreases in size over time and holds lesser significance during the Great Recession. ${ }^{13}$ The region of origin continues to have the largest impact in terms of determining whether one works abroad, with the most marked effect in the more depressed regions.

\section{Labor market outcomes in the receiving countries and upon return}

After EU accession and before the start of the economic and financial crisis, a significant share of migrants from Slovakia were young people, typically university students or fresh graduates who explored new destinations, such as Ireland and the UK. As a result, brain drain became a widely discussed concern during the period. Key questions include the extent to which post-enlargement migrants practiced their skills or acquired new competences, whether their migration plans were permanent, temporary or circular and to what extent they were able to integrate and use their skills in the Slovak labor if they returned.

\footnotetext{
${ }^{12}$ Full results available upon request. It is worth noting that after EU accession, compared to 2003 and 2004, workers of Hungarian ethnicity and the Roma (especially in 2010 but also 2007) were more likely to migrate for work, ceteris paribus. This may signal a higher responsiveness of ethnic minorities to liberalization of mobility within the EU, although the scope of comparison is limited here.

${ }^{13}$ This may be due to worsened employment opportunities in receiving countries, new active labor market policies implemented as a reaction to the Great Recession in Slovakia, or due to an increased complexity of the relationship between migration and unemployment during the economic downturn, which requires further research.
} 
As a point of departure, we evaluate the labor market outcomes of post-enlargement migrants in key receiving countries. Due to data availability issues, most of the studies considered EU8 migrants as an aggregate category. ${ }^{14}$ We first review such studies, hypothesizing that the Slovak migrants do not significantly deviate from the general patterns observed for EU8 labor migrants in the EU, before complementing them by providing insights into the key patterns observed for Slovak migrants.

A marked feature of post-accession migration to the UK and Ireland, two countries that together with Sweden opened their labor markets immediately with the 2004 enlargement, is a wide mismatch between the level of educational attainment and the jobs taken by EU8 migrants. In the majority of cases, migrants became employed in jobs below their qualifications, paid worse in jobs of a lower quality, working in sectors such as administrative work, tourism, construction, agriculture, elderly care, entertainment and domestic work (Favell 2008; Kahanec and Kureková 2013; Kahanec and Zimmermann 2010; Kahanec 2013; Kahanec 2012; Ciupijus 2011). Interestingly, downskilling seems to have been selective, whereby those with vocational education generally worked in occupations commensurate with their skills, while migrants with tertiary education were more likely to take on jobs in elementary occupations (Pollard, Latorre, and Sriskandarajah 2008). However, for earlier cohorts of EU8 migrants, Drinkwater, Eade, a Garapich (2009) find that a relatively large proportion of those who had arrived between 2000 and 2003 worked in high or intermediate occupations after some time spent in the UK. This suggests that the observed downskilling may be at least in part a temporary phenomenon, as EU8 migrants tend to climb up the occupation ladder with time, consequently improving matching between qualifications and jobs.

\footnotetext{
${ }^{14}$ EU8 refers to the countries that joined the EU in 2004, minus Cyprus and Malta. These are the Czech Republic, Estonia, Hungary, Latvia, Lithuania, Poland, Slovakia, Slovenia. EU2 denotes Bulgaria and Romania, and EU12 denotes EU8, EU2 and Cyprus and Malta together.
} 
The high employment rates of EU8 migrants in the UK corroborate that the vast majority of post-enlargement migrants came there to work. Relatedly, their welfare take up and reliance on benefits has been significantly lower than that of the other native and immigrant groups, even when controlling for demographic characteristics (Dustmann, Frattini, and Halls 2010; Kahanec and Zimmermann 2010; Clark, Drinkwater, and Robinson 2014, this volume). Related to the predominance of low-skilled employment, the earnings of EU8 migrants in the UK were among the lowest relative to other non-EU immigrant groups, controlling for demographic characteristics (Clark and Drinkwater 2008; Drinkwater, Eade, and Garapich 2009; Blanchflower and Lawton). ${ }^{15}$ Factors such as sectors of employment, low-skilled occupation or a lack of English language proficiency have been some of the important determinants of the less favorable earning outcomes and often precarious work conditions of EU8 immigrants (Pollard, Latorre, and Sriskandarajah 2008; Clark and Drinkwater 2008; Blanchflower and Lawton; Dustmann and Weiss 2007; Burrell 2010). Additionally, it has been argued that the mismatch between the acquired skill levels and earnings of EU8 migrants can be understood in the context of their own migration strategies, which were short-term with the aim of spending or investing earnings at home rather than abroad (Clark and Drinkwater 2008).

Migration from the EU8 to Ireland followed similar outcomes in many respects. Based on the Irish census, in 2006 (peak of EU8 immigration to Ireland), the majority of EU8 migrants (79\%) were at work, and mainly as employees, while only a very small share was self-employed. According to the Quarterly National Household Survey, in the first quarter of 2007, right after Bulgaria and Romania joined the EU but still before the Great Recession, the employment rate (the number of employed over all persons aged 15 years and over) of EU12 immigrants was $84.2 \%$, in contrast to $59.2 \%$ for Irish nationals. The unemployment rates for

\footnotetext{
${ }^{15}$ Drinkwater, Eade, and Garapich $(2009,172)$ in their analysis of LFS data find that average hourly earnings for recent Polish and other EU8 migrants are around $£ 6$ which is consistent with the information in the WRS.
} 
the two groups were $5.8 \%$ and $4.2 \%$, respectively. During the Great Recession, the employment rate decreased to $62.7 \%$ for EU12 immigrants and $50.4 \%$ for the natives in the first quarter of 2011. The corresponding figures for unemployment rates were $20.4 \%$ and $13.7 \%$. By early 2014, the unemployment rates had decreased to $15.7 \%$ for immigrants from EU12 plus Croatia and 11.4\% for Irish nationals. In the same period, the employment rates increased to 68.2 for immigrants from EU12 plus Croatia and 51.7\% for the natives. These figures indicate that EU12 migrants suffered during the Great Recession disproportionately due to being employed in crisis-sensitive sectors; but a parallel interpretation is that EU12 migrants helped Ireland to absorb negative economic shocks during the Great Recession.

\section{Return migration}

While the debate concerning the length of stay preferences and return patterns of EU8 migrants remains open (Burrell 2010; Cook, Dwyer, and Waite 2011), previous studies regarding Slovak migrants as well as the mapping of migrants' profiles above suggest that young migrants from the new destinations have been returning and their propensity to migrate is currently much lower (Kureková 2011b). However, precise numbers concerning the rate of return and labor market outcomes of return migrants are not readily available (but see Zaiceva and Zimmermann 2014).

We have been able to gather data about the number of jobseekers registered in the Slovak unemployment register by the previous country of employment, along with a number of demographic characteristics, which indirectly helps to map relative 'return into unemployment' to proxy "unemployment rate" of returnees by country of work abroad in a given year. In Table 4, columns B, we show data about return migrants who registered as unemployed with labor office by the country of previous employment between 2009 and 2011. In absolute numbers, it can be seen that most migrants have 'returned to 
unemployment' from the Czech Republic. We measure the relative rate of return into unemployment by calculating the ratio of registered migrant returnees over the total number of Slovak workers in a given destination country ('working abroad' as provided in the Slovak LFS data) plus the number of registered migrant returnees. We also calculate the corresponding unemployment rate among the working population in Slovakia (the last row in Table 4). Apart from Italy and Ireland (only in 2009), the rate of return into registered unemployment from abroad is lower than the corresponding rate for workers in Slovakia. This suggests that EU labor markets absorb Slovak workers well. However, we are unable to capture whether any Slovak migrants claim unemployment in the given host countries ${ }^{16}$, whether returnees prefer not to register as unemployed, and it also could be that best workers with low unemployment probability are overrepresented among migrants.

The rate of return into unemployment however helps us to shed light on a combined effect of labor market performance in the host countries and Slovakia. In particular, we can imply an increasing absorptive capacity of the Austrian labor market (rising inflows of Slovak workers, but little return into unemployment) and a declining absorptive capacity of the Italian, but also German, labor market. In fact, from 2010 to 2011 absorptive capacity deteriorated also in the Czech Republic, Hungary and Ireland. ${ }^{17}$ These trends correspond to general labor market developments in these countries during that period, with Italy being affected by the crisis much more significantly than other key destinations, such as Austria; and may also reflect the more recent deterioration in the Czech Republic or Hungary.

\footnotetext{
${ }^{16}$ According to existing evidence, welfare take-up of EU8 migrants is lower than of other migrants groups in the UK (Dustmann, Frattini, and Halls 2010). Jobseeker allowance is the most frequent type of benefit received - in early 2011, 45\% of working age benefit claims were for jobseekers allowance (DWP 2012, 8).

${ }^{17}$ A related factor could be that returnees from some countries (e.g. Italy) find it more difficult to find employment in Slovakia or elsewhere than returnees from other countries (e.g. Austria).
} 


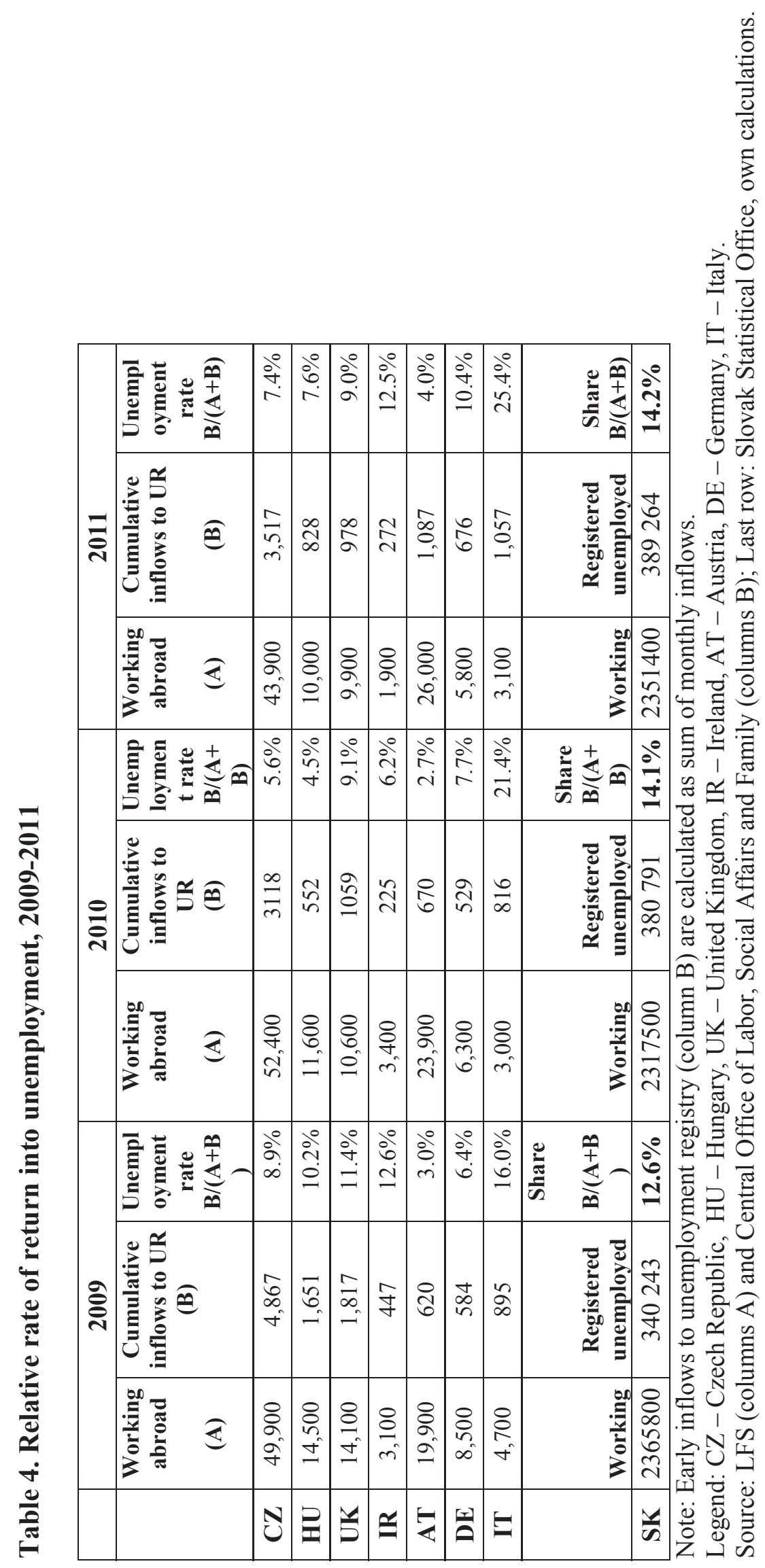


Table 5 summarizes some aggregate demographic characteristics of the stock of return migrants in the unemployment register and the characteristics of the outflows in March 2012 (latest available). Most people who have returned and registered with the labor office are young, between 20 and 34 years of age, confirming the hypotheses put forward above that young migrants have been returning. Apprenticeship and secondary education are the most commonly held qualifications of returnees, which corresponds to the description of emigrant education profiles. Most registered returnees were employed in elementary occupations, followed by trades and services and sales. Interestingly, a non-negligible number of people who are highly educated and employed in high-skilled occupations have also returned.

Overall, the chance to integrate into labor market, measured as the share of outflows from the unemployment register relative to the stock of unemployed, is higher for those who are more educated, previously employed in more skilled occupations and the younger/prime age workers. These trends are in line with the overall patterns that the least educated labor market entrants and the elderly are among the most disadvantaged workers (Brožovičová et al. 2013).

While few empirical works have studied how employers value working experience gained abroad, some evidence suggests that it gives a positive signal through demonstrating a set of qualities desirable on the labor market, such as foreign language proficiency, independence or self-initiative (Kureková 2011b; Williams and Baláž 2005).

We finally compare the outflow rates from unemployment registry of return migrants to those of the general population. In March 2012, 13\% of the registered stock of unemployed previously employed abroad left the registry (Table 5). This compares to $6.1 \%$ outflow rate of 
total unemployed, ${ }^{18}$ which indeed hints at an easier labor market integration of people previously employed abroad.

The impact of migration policy and transitional arrangements

Evaluating the patterns of migration discussed above, we can infer that the particular directionality of labor flows from Slovakia after EU accession was partly affected by the policy framework and selective liberalization of labor markets. ${ }^{19}$ Those countries that immediately liberalized their labor markets attracted a rising and significant share of Slovak migrants, especially the young; however, this pattern was also closely connected to the labor demand and working opportunities in these destination countries. Once the opportunities ceased to exist, the number of new arrivals significantly declined and many Slovak migrants returned home or went elsewhere.

On the other hand, Austria and Germany, in spite of restrictions on the free entry of workers applied until May 2011, continued to attract steady (Germany) or strongly growing (Austria) numbers of migrants from Slovakia. This suggests that the transitory policy frameworks were only partially effective. In particular, the structure of labor demand in Austria (i.e. demand in social care sector) strongly matching redundant labor in Slovakia (unemployed middle-aged women) to some extent overrode the transitional arrangements, which were in fact adapted to facilitate inflows of social care workers.

\footnotetext{
${ }^{18}$ In March 2012, Slovakia had 408,404 registered unemployed, in that month 25,096 deregistered yielding outflow rate of $6.1 \%$. Source: Central Office of Labor, Social Affairs and Family, March 2012, registered unemployment statistics.

${ }^{19}$ See Kahanec, Pytlíková and Zimmermann (2014), for a discussion about the effects of transitional arrangements.
} 

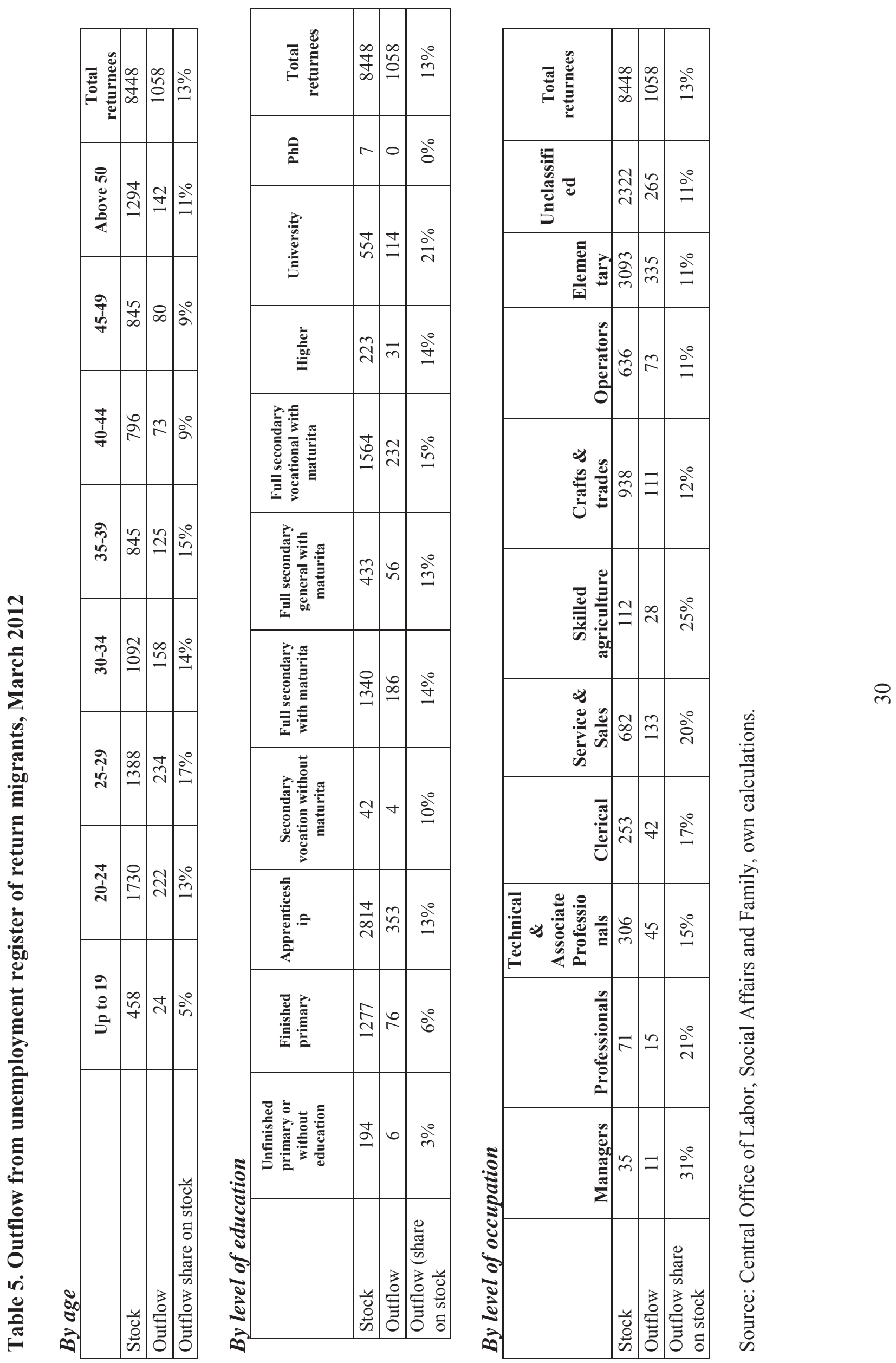

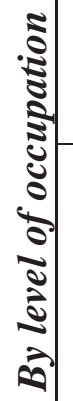

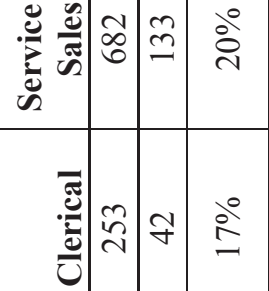

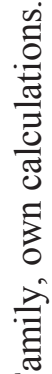

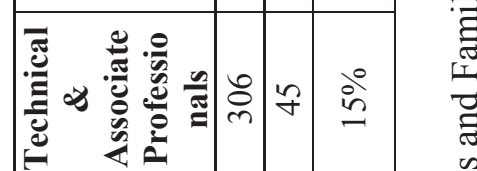

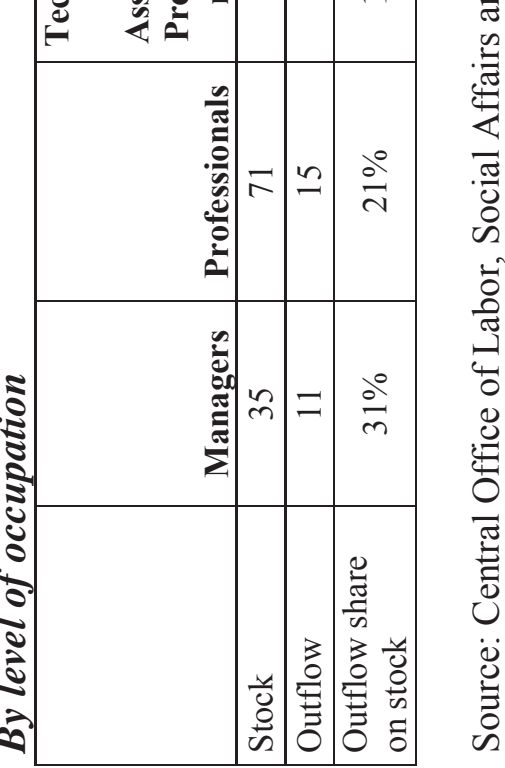




\section{Conclusions}

This paper evaluates the dynamics of migration flows between Slovakia and the rest of the EU following Slovakia's accession in 2004, as well as during the Great Recession. We review available data and studies on migration flows and provide our own analysis of the selectivity of Slovak migrants over time. We shed light on the interaction of migration trends with the economic and social trajectory of the country and the potentials for enhanced allocative efficiency and brain gain, or alternatively the risk of brain drain, ensuing from out-migration and return migration.

We find that labor mobility serves as an important adjustment mechanism in the country and more generally in the EU labor market. We observe multiple shifts of migrant profiles reflecting shifting economic and social asymmetries, but also policy changes, before and during the Great Recession. When conditions in the main receiving countries worsened, migration flows declined and redirected to other destination countries with more favorable labor market opportunities. In particular, migration to Ireland and the UK, which were among the first in the EU to have been stricken by the crisis, declined, whereas migration to the less affected labor markets, such as Austria, increased. This has been reflected in a changed profile of labor migrants, away from the young and university students to the breadwinner profile of emigrants.

The outflow of the young and well-educated migrants declined during the Great Recession. We conjecture that due to the short-term nature of post-accession migration, no massive brain waste occurred; however, given that young migrants mainly took up employment in low-skilled jobs, whereby the contribution to their substantive skills development was limited (although they possibly still developed useful soft skills and were in a better position compared to the counterfactual of staying back home), we cannot exclude some waste of their potential. 
Towards the late-2000s, migrant profiles 'aged' hand in hand with a decline in the outflow of youth to the UK and Ireland and a rise in the outflows to Austria, which attracts mainly aged female workforce into the personal and social care services. Demand in this sector in Austria has been more robust, and perhaps countercyclical, with respect to the Great Recession and able to absorb a significant share of particularly female labor. This shift has also marked a reallocation of migrants across sectors during the Great Recession, away from operators and elementary occupations and into services and sales. Overall, while emigration rates from Slovakia declined due to economic downturn in the main receiving countries, they have remained above the pre-accession levels thus far.

In an analysis of the determinants of out-migration from Slovakia to the rest of the EU, we find that whereas individual demographic characteristics mattered for the selectivity of migration, the conditions in the region of origin have had a significant impact on the propensity to work abroad, with less affluent regions pushing labor force on a migration trajectory. Unemployment status is shown to be a significant predictor of migration, although its net impact has declined over time. This analysis also indicates that migration flows respond to economic shocks in Slovakia and receiving countries.

While measuring return migration and the integration of return migrants is precluded by the lack of data, we infer some trends by combining data in destination countries and administrative data concerning registered jobseekers who had worked abroad. We find that the chances of individuals previously working abroad exiting the unemployment registry are higher for those who are more educated, worked in more skilled occupations and of younger age. We also find that receiving labor markets less affected by the crisis (e.g. Austria) were able to absorb growing numbers of Slovak migrants, while those more significantly affected by the crisis (e.g. Italy) were shedding immigrant labor from Slovakia. 
In sum, while transitional arrangements restricting free mobility to some EU member states have partly affected migration flows, we argue that migration flows between Slovakia and the rest of the EU adjusted flexibly to the changing conditions of supply and demand at home and abroad. Against the background of a relatively liberal labor market regulation in Slovakia and liberalized access to labor markets in other EU member states, this adjustment concerned both the directionality and composition of migration flows. Overall, we conclude that free movement of labor and post-accession mobility of Slovak workers have served as an important adjustment mechanism during the Great Recession. 


\section{Bibliography}

Anacka, Marta, Agnieszka Fihel, and Pawel Kaczmarczyk. 2014. "Migration as an Asset? Polish Returnees at the Time of the Crisis." In Migration and the Great Recession: Adjustments in the Labour Market of an Enlarged European Community', edited by Martin Kahanec and Klaus F. Zimmermann. Springer Verlag.

Bahna, Miloslav. 2012a. Migrácia zo Slovenska po vstupe do Európskej únie. Bratislava: Veda.

. 2012b. "Slovak Care Workers in Austria: Household Migration Strategy or Product of Austrian Welfare Policies?" Under review. Ústavný seminár Sociologického ústavu SAV.

http://www.sociologia.sav.sk/cms/uploaded/1385_attach_seminar_opatrovatelky2011. pdf.

. 2012c. "Intra-EU Migration from Slovakia." European Societies, July, 1-20. doi:10.1080/14616696.2012.707669.

Blanchflower, David.G., and Helen Lawton. "The Impact of the Recent Expansion of the EU on the UK Labor Market." EU Labor Markets After Post-Enlargement Migration, $181-215$.

Brožovičová, Klára, Brian Fabo, Martin Kahanec, and Vera Messing. 2013. Overview of the Labour Market Situation of Low-Educated and Roma Population and Regulations Affecting Their Employment. CELSI Research Report 4. Bratislava: CELSI. http://ideas.repec.org/p/cel/report/4.html.

Burrell, Kathy. 2010. "Staying, Returning, Working and Living: Key Themes in Current Academic Research Undertaken in the UK on Migration Movements from Eastern Europe." Social Identities 16 (3): 297-308. doi:10.1080/13504630.2010.482401.

Ciupijus, Zinovijus. 2011. "Mobile Central Eastern Europeans in Britain: Successful European Union Citizens and Disadvantaged Labour Migrants?" Work, Employment \& Society 25 (3): 540-50. doi:10.1177/0950017011407962.

Clark, Ken, and Stephen Drinkwater. 2008. "The Labour-Market Performance of Recent Migrants." Oxford Review of Economic Policy 24 (3): 496-517.

Clark, Ken, Stephen Drinkwater, and Catherine Robinson. 2014. "Free Movement of Workers in an Enlarged European Union: Institutional Underpinnings of Economic Adjustment." In Migration and the Great Recession: Adjustments in the Labour Market of an Enlarged European Community', edited by Klaus F. Zimmermann and Martin Kahanec. Springer Verlag.

Cook, Joanne, Peter Dwyer, and Louise Waite. 2011. "The Experiences of Accession 8 Migrants in England: Motivations, Work and Agency." International Migration 49 (2): $54-79$.

Drinkwater, S., J. Eade, and M. Garapich. 2009. "Poles Apart? EU Enlargement and the Labour Market Outcomes of Immigrants in the United Kingdom." International Migration 47 (1): 161-90.

Dustmann, Christian, Tommaso Frattini, and Caroline Halls. 2010. "Assessing the Fiscal Costs and Benefits of A8 Migration to the UK*." Fiscal Studies 31 (1): 1-41.

Dustmann, Christian, and Y. Weiss. 2007. "Return Migration: Theory and Empirical Evidence from the UK." British Journal of Industrial Relations 45 (2): 236-56.

DWP. 2012. Nationality at Point of National Insurance Number Registration of DWP Benefit Claimants: February 2011 Working Age Benefits. Department for Work and Pensions, UK. 
https://www.gov.uk/government/uploads/system/uploads/attachment_data/file/196677 /nat_nino_regs.pdf.

Elsner, Benjamin. 2013. "Does Emigration Benefit the Stayers? Evidence from EU Enlargement." Journal of Population Economics 26 (2): 531-53. doi:10.1007/s00148012-0452-6.

Favell, A. 2008. "The New Face of East-West Migration in Europe." Journal of Ethnic and Migration Studies 34 (5): 701-16.

Fertig, Michael, and Christoph Schmidt. 2001. "First-and Second-Generation Migrants in Germany-What Do We Know and What Do People Think?" IZA Discussion Paper No. 286. http://papers.ssrn.com/sol3/papers.cfm?abstract_id=267223.

Fidrmuc, Jan. 2004. "Migration and Regional Adjustment to Asymmetric Shocks in Transition Economies." Journal of Comparative Economics 32 (2): 230-47.

Gelvicka, Marcela. 2009. "Robotníci Z Írska Chcú Pracovat' Na Našich Stavbách (Workers from Ireland Want to Work on Our Construction Sites)." Www.sme.sk. http://www.sme.sk/c/4891389/robotnici-z-irska-chcu-pracovat-na-nasichstavbach.html.

Gerdes, and Eskil Wadensjö. 2014. "Returning Home at Times of Trouble? Return Migration of EU Enlargement Migrants during the Crisis." In Migration and the Great Recession: Adjustments in the Labour Market of an Enlarged European Community', edited by Martin Kahanec and Klaus F. Zimmermann. Springer Verlag.

Hatton, Timothy J. 2005. "Explaining Trends in UK Immigration." Journal of Population Economics 18 (4): 719-40.

Hlinčíková, Miroslava, Daniela Lamačková, and Martina Sekulová. 2011. Migranti a Migrantky Na Trhu Práce v SR - Identifikácia a Prekonávanie Bariér Diskriminácie. Bratislava: Inštitút pre verejné otázka (IVO). http://www.ivo.sk/buxus/docs//publikacie/subory/Migranti_a_migrantky_na_trhu_pra ce.pdf.

Holland, Dawn, Tatiana Fic, Pawel Paluchowski, Ana Rincon-Aznar, and Lucy Stokes. 2011. "Labour Mobility within the EU-The Impact of Enlargement and Transitional Arrangements." National Institute of Economic and Social Research Discussion Paper, no. 379. http://niesr.ac.uk/sites/default/files/publications/050811_152043.pdf.

Jurajda, Štěpán, and Katherine Terrell. 2009. "Regional Unemployment and Human Capital in Transition Economies.” Economics of Transition 17 (2): 241-74. doi:10.1111/j.14680351.2009.00351.x.

Kahanec, Martin. 2012. Skilled Labor Flows: Lessons from the European Union. Report under the World Bank ASEAN Labor Markets program, also IZA Research Report no. 49.

. 2013. "Labor Mobility in an Enlarged European Union." In International Handbook on the Economics of Migration, edited by Amelie F. Constant and Klaus F. Zimmermann, 137-52. Edward Elgar Publishing.

Kahanec, Martin, and Brian Fabo. 2013. "Migration Strategies of the Crisis-Stricken Youth in an Enlarged European Union." Transfer: European Review of Labour and Research 19 (3): $365-80$.

Kahanec, Martin, and Lucia Kureková. 2013. "European Union Expansion and Migration." Edited by Immanuel Ness. The Encyclopedia of Global Human Migration. WileyBlackwell Publishing.

Kahanec, Martin, Mariola Pytlikova, and Klaus F. Zimmermann. 2014 (forthcoming). "Free Movement of Workers in an Enlarged European Union: Institutional Underpinnings of Economic Adjustment." In Migration and the Great Recession: Adjustments in the 
Labour Market of an Enlarged European Community', edited by Martin Kahanec and Klaus F. Zimmermann. Springer Verlag.

Kahanec, Martin, and K. F. Zimmermann. 2010. "Migration in an Enlarged EU: A

Challenging Solution?" Five Years of an Enlarged EU, 63-94.

Kureková, Lucia. 2011a. "The Effects of Structural Factors in Origin Countries on Migration:

The Case of Central and Eastern Europe." IMI Working Paper no. 45.

http://papers.ssrn.com/sol3/papers.cfm?abstract_id=1962349.

. 2011b. "From Job Search to Skill Search: Political Economy of Labor Migration in Central and Eastern Europe". Central European University.

http://www.etd.ceu.hu/2011/kurekova_lucia.pdf.

. 2013. "Welfare Systems as Emigration Factor: Evidence from the New Accession

States.” JCMS: Journal of Common Market Studies 55 (4): 721-39. doi:10.1111/jcms.12020.

Pollard, N., M. Latorre, and D. Sriskandarajah. 2008. Floodgates or Turnstiles?: Post-EU Enlargement Migration Flows to (and From) the UK. Institute for Public Policy Research.

Pryymachenko, Yana, Klas Fregert, and Fredrik NG Andersson. 2011. The Effect of Emigration on Unemployment: Evidence from the Central and Eastern European EU Member States. Department of Economics, Lund University. http://www.nek.lu.se/publications/workpap/papers/WP11_32.pdf.

Puhani, Patrick A. 2001. "Labour Mobility: An Adjustment Mechanism in Euroland? Empirical Evidence for Western Germany, France and Italy." German Economic Review 2 (2): 127-40. doi:10.1111/1468-0475.00031.

Rutkowski, Jan. 2007. "Labor Markets in EU8+2: From the Shortage of Jobs to the Shortage of Skilled Workers." World Bank EU8+2 Regular Economic Report, Part II. http://papers.ssrn.com/sol3/papers.cfm?abstract_id=1078895.

Williams, Allan M., and Vladimir Baláz. 2004. "From Private to Public Sphere, the Commodification of the Au Pair Experience? Returned Migrants from Slovakia to the UK." Environment and Planning A 36 (10): 1813-33. doi:10.1068/a36279.

Williams, Allan M., and Vladimir Baláž. 2005. "What Human Capital, Which Migrants? Returned Skilled Migration to Slovakia From the UK." International Migration Review 39 (2): 439-68. doi:10.2307/27645504.

Zaiceva, Anzelika, and Klaus F. Zimmermann. 2014 (forthcoming). "Returning Home at Times of Trouble? Return Migration of EU Enlargement Migrants during the Crisis." In Migration and the Great Recession: Adjustments in the Labour Market of an Enlarged European Community', edited by Martin Kahanec and Klaus F.

Zimmermann. Springer Verlag.

Zimmermann, Klaus F., Martin Kahanec, Amelie Constant, Don DeVoretz, Lilya Gataullina, and Anzelika Zaiceva. 2008. Study on the Social and Labour Market Integration of Ethnic Minorities. Final Report, European Commission, DG Employment, Social Affairs and Inclusion. IZA Research Report no. 16. http://zanran_storage.s3.amazonaws.com/www.iza.org/ContentPages/27490736.pdf. 
www.celsi.sk

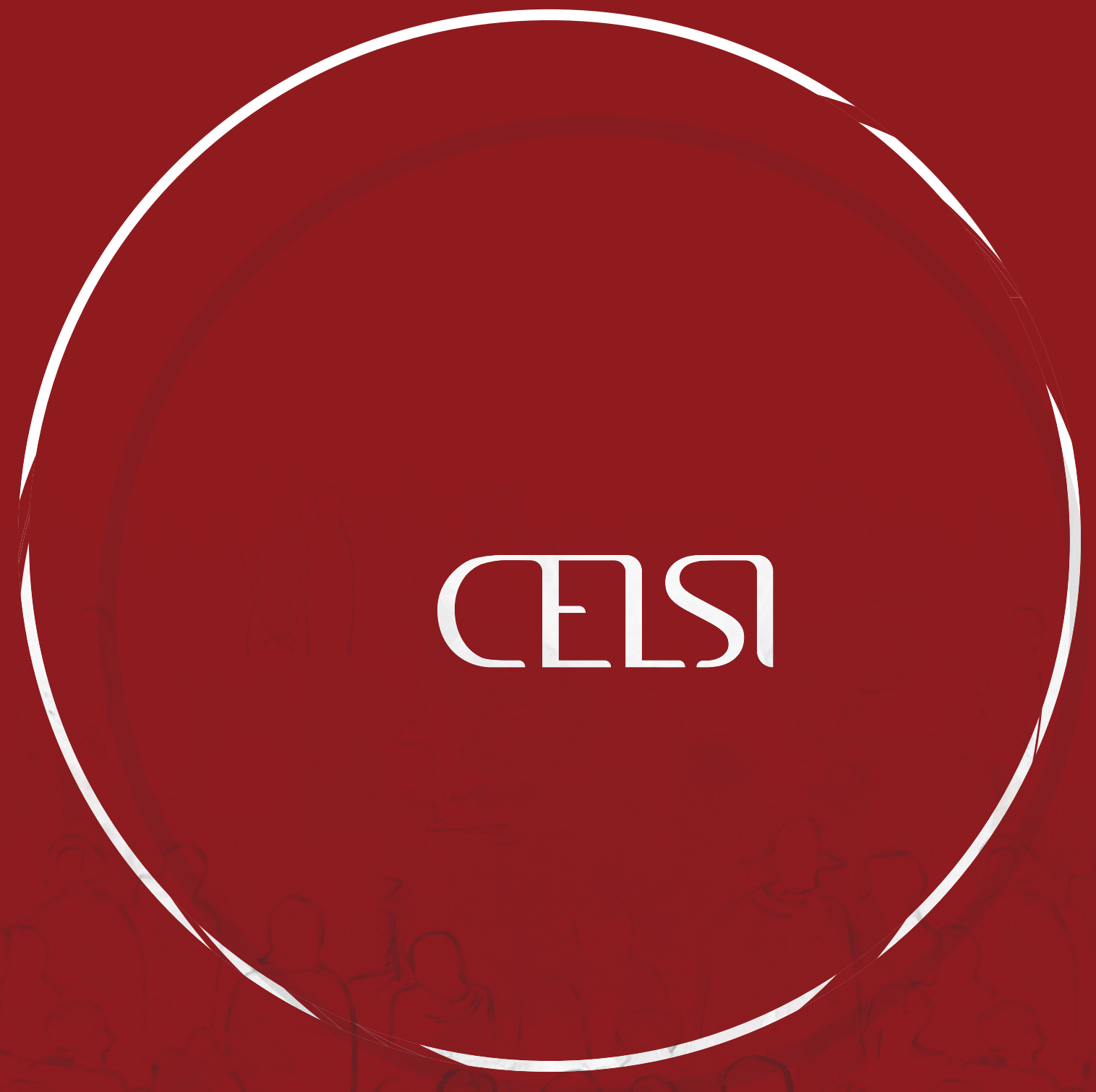

